Southern Methodist University

SMU Scholar

Faculty Journal Articles and Book Chapters

Faculty Scholarship

1994

\title{
Women's Jury Service: Right of Citizenship or Privilege of Difference?
}

Joanna L. Grossman

Southern Methodist University, Dedman School of Law

\section{Recommended Citation}

Joanna L. Grossman, Women's Jury Service: Right of Citizenship or Privilege of Difference?, 46 Stanford Law Review 1115 (1994) (Note)

This document is brought to you for free and open access by the Faculty Scholarship at SMU Scholar. It has been accepted for inclusion in Faculty Journal Articles and Book Chapters by an authorized administrator of SMU Scholar. For more information, please visit http://digitalrepository.smu.edu. 


\title{
NOTES
}

\section{Women's Jury Service: Right of Citizenship or Privilege of Difference?}

\author{
Joanna L. Grossman*
}

The Supreme Court recently declared that peremptory challenges based on sex, like those based on race, violate the Equal Protection Clause of the Fourteenth Amendment. In this note, Joanna Grossman argues that the Court has finally established the right of women to serve on juries. Women's rights advocates had fought for this right for more than a century, but courts refused to recognize that women were harmed by exclusion from juries and denied any connection between women's jury service and citizenship. Instead, courts focused on gender difference and only eliminated legal barriers to women's jury service when it was necessary to uphold the rights of defendants. By contrast, the Court recognized the citizenship-based right of blacks to serve over a hundred years earlier. With this decision, the Supreme Court corrected this longstanding disparity in the treatment of race and sex in jury selection.

\section{INTRODUCTION}

Defendants in criminal proceedings do not have the only cognizable legal interest in nondiscriminatory jury selection. People excluded from juries because of their race are as much aggrieved as those indicted and tried by juries chosen under a system of racial exclusion. ${ }^{1}$

Until 1986, parties could use peremptory challenges with near impunity to exclude African-Americans from juries in individual criminal trials. But in the landmark case Batson v. Kentucky, ${ }^{2}$ the Supreme Court held that such conduct violated the Equal Protection Clause. A series of cases extended the Batson doctrine to apply to the use of race-based peremptory challenges in civil as well as criminal cases and regardless of whether the parties and the excluded jurors share the same race. In these cases, as well as in many that had come before, the Supreme Court recognized that racially discriminatory peremptory chal-

* Third-year law student, Stanford Law School. I am grateful to Professor Barbara Babcock for her inspiration, friendship, and expertise on women and juries. I am also indebted to Professor Thomas Grey, Alison Grossman, and Brad Joondeph for extremely helpful comments on earlier drafts, and to my parents, Mary and Joel Grossman, and Grant Hayden for their support. Thanks as well to the editors and staff of the Stanford Law Review.

1. Carter v. Jury Comm'n, 396 U.S. 320, 329 (1970).

2. Batson v. Kentucky, 476 U.S. 79 (1986). 
lenges "harm[ ] the excluded jurors and the community at large,"3 by denying prospective jurors a basic right of citizenship and jeopardizing the public's perception of a verdict's fairness.

Not until 1994, however, did the Court acknowledge a connection between citizenship and jury service for women. In J.E.B. v. T.B., the Court held that peremptory challenges based on sex violate the equal protection rights of prospective jurors. ${ }^{4}$ The decision corrected a century of differential treatment between race and sex in the jury context, which persisted due to the belief that women were not harmed, and perhaps even were helped, by the exclusion.

The differing perception of the harm inflicted on blacks and on women by exclusion explains the historical treatment of sex-based jury exclusions by the courts, as well as the monumental importance of the underlying analytical shift that the Court made in J.E.B. Recognizing the stigmatic effect of race-based exclusion, the courts eliminated legal barriers to jury service for blacks. Courts based their decisions more on the rights of citizens to serve on juries than on the right of defendants to be tried by a representative jury. They viewed these cases as remedial - bringing blacks' rights up to those of others. For women, though, exclusion was seen to inflict harm neither on the excluded women nor on the community. Consequently, instead of recognizing jury service as a right of female citizens, courts treated women's jury service as merely incidental to defendants' rights, expanding women's jury service only where necessary to protect the rights of others.

The difference in courts' treatment of race and sex in this context in turn explains the focus of the longstanding debate about women and jury service. Because excluding qualified women was tolerated by courts, the argument in favor of having women on juries centered on the different perspective they would bring to the jury box. As the Court implicitly recognized in J.E.B., the time has come to assess race-based and sex-based peremptory challenges from the same perspective-one which accounts for the rights of jurors, as well as defendants, by treating jury service as a right of citizenship rather than a privilege of difference. Continued differential treatment would ignore history and disrupt the doctrinal development of jury service as a right of citizenship.

Part I of this note constructs two analytical models of the right to serve on juries, based on the purposes juries serve in our legal system. The first model emphasizes the factfinding role of juries, in which a prospective juror's right to serve derives from the defendant's right to an impartial jury. The second model treats jury service as an essential duty of citizenship, carrying an independent right not to be excluded on the basis of group membership. Part II discusses the nature of and limits on peremptory challenges, and compares the historically inconsistent treatment of race and sex in the jury selection context. Part III traces the history of women's struggle to gain the right to serve as jurors,

3. Powers v. Ohio, 499 U.S. 400,406 (1991).

4. 114 S. Ct. 1419 (1994) (reaffirming that "potential jurors ... have an equal protection right to jury selection procedures that are free from state-sponsored group stereotypes rooted in, and reflective of, historical prejudice"). 
concluding that the means by which women opened the door to jury service (limited by the framework under which courts were willing to view the issue) may have contributed to the longstanding, anomalous treatment of challenges to jury selection procedures that discriminate on the basis of sex. Ultimately, this note concludes that, through J.E.B., the Supreme Court has finally begun to view women's right to serve on juries through a different lens-one that magnifies citizenship rather than difference. By adopting this perspective, the Supreme Court has, by implication in a case about excluding men, finally established the unqualified right of women to serve on juries.

\section{Two Models of Jury Selection}

In our legal system, the jury both acts as an impartial factfinder and provides a forum for civic participation. These separate roles depend upon the protection of distinct rights, and require different limitations on the selection of jurors. Thus, courts have relied on two distinct models to analyze jury selection questions. The first-the representativeness model-focuses on the protections necessary to preserve the right of defendants to an impartial jury. By contrast, the second-the citizenship model-emphasizes the safeguards needed to ensure that eligible citizens, who have a right to participate in the jury process, are not wrongfully excluded from juries.

\section{A. The Ideal of Representativeness}

The image of the jury as a neutral factfinder has long prevailed in our legal system, and insulation from the government and judiciary plays an important role in ensuring this neutrality. ${ }^{5}$ In addition to this freedom from government intervention, the factfinding role contemplates a jury comprising diverse members who reflect a society of the defendant's peers.

Representativeness arguably infuses juries with a greater likelihood of arriving at the "truth" in a given case, thus serving their factfinding function. In any event, the desire for representativeness stems primarily from the belief that "a jury composed of individuals with a wide range of experiences, backgrounds, and knowledge is more likely to perceive the facts from different perspectives and thus engage in a vigorous and thorough debate." 6 The Supreme Court relied on this belief in Apodaca v. Oregon, concluding that "a jury will come to such a [proper] judgment as long as it consists of a group of laymen

5. See Dale W. Broeder, The Functions of the Jury: Facts or Fictions?, 21 U. CHr. L. REv. 386, 387 (1954) (concluding that "[t]he jury's central legal function is to resolve the factual disputes involved in a law suit"). In Duncan v. Louisiana, Justice White explained the importance of jury insulation:

A right to jury trial is granted to criminal defendants in order to prevent oppression by the Government .... Providing an accused with the right to be tried by a jury of his peers gave him an inestimable safeguard against the corrupt or overzealous prosecutor and against the compliant, biased, or eccentric judge .... Fear of unchecked power ... found expression in ... this insistence upon community participation in the determination of guilt or innocence. 391 U.S. 145, 155-56 (1968).

6. Valerie P. Hans \& Neil Vidmar, Judging the Jury 50 (1986). 
representative of a cross-section of the community who have the duty and the opportunity to deliberate ... on the question of a defendant's guilt."7

By virtue of its perceived contribution to accurate factfinding, the concept of representativeness is now firmly entrenched in our legal system. ${ }^{8}$ In fact, commentators often blame seemingly erroneous factfinding on distortions in jury composition or selection;" thus, "[r]egardless of whether or not the composition of the jury actually makes a difference in any particular case, people look to the composition of the jury to explain verdicts." 10

The Supreme Courts commitment to representativeness is based on the Sixth Amendment's mandate for an impartial jury, which has been interpreted to require that criminal defendants be tried by a jury drawn from a fair crosssection of the community. ${ }^{11}$ The longstanding commitment to representativeness is reflected in the Supreme Court's holdings in various jury selection cases. ${ }^{12}$ In one of its earliest statements affirming this commitment, the Supreme Court explained in Glasser v. United States that

the proper functioning of the jury system, and, indeed, our democracy itself, requires that the jury be a 'body truly representative of the community', and not the organ of any special group or class. ... [Thus] the officials charged with choosing federal jurors ... must not allow the desire for competent jurors to lead them into selections which do not comport with the concept of the jury as a cross-section of the community. Tendencies, no matter how slight, toward

7. 406 U.S. $404,410-11$ (1972) (plurality opinion).

8. HANS \& VIDMAR, supra note 6, at 51 (explaining that although the "road to representativeness has been a long and rocky one," the constitutional right to a jury trial now finally includes "the right to draw a jury from a truly representative cross section of the population").

9. For example, note the widespread astonishment at the acquittal of the police officer defendants by a jury without any African-Americans in the Rodney King beating trial. See, e.g., Marcia Chambers, Sua Sponte, NAT'L LJ., May 18, 1992, at 13 (concluding that the change of venue from ethnically diverse Los Angeles to predominantly white suburban Simi Valley likely affected the verdict); Erwin Chemerinsky, How Could the King Jury Do That?, Legal Times, May 11, 1992, at 23 (observing that the white, conservative jury probably had no sense of the true police-citizen dynamic in Los Angeles); Joseph Kelner \& Robert S. Kelner, The Rodney King Verdict and Voir Dire, N.Y. L.J., May 26, 1992, at 3 ("The ethnic, philosophical and social predilections of Ventura County's residents predictably provided jurors with a penchant for finding reasonable doubt of guilt despite the police brutality.").

10. HANS \& VIDMAR, supra note 6, at 51 (emphasis added) (concluding that a representative jury is favorable "not only for fact-finding but also for legitimation); see also Taylor v. Louisiana, 419 U.S. 522,530 (1975) (noting that "[c]ommunity participation in the administration of the criminal law ... [is] critical to public confidence in the faimess of the criminal justice system").

11. The Sixth Amendment provides that "[i]n all criminal prosecutions, the accused shall enjoy the right to a speedy and public trial, by an impartial jury ...." U.S. ConsT. amend. VI.

12. See, e.g., Taylor, 419 U.S. at 527 (affirming that the Supreme Court "has unambiguously declared that the American concept of the jury trial contemplates a jury drawn from a fair cross section of the community"); Peters v. Kiff, 407 U.S. 493, 500 (1972) (observing that the Sixth Amendment comprehends a fair possibility for obtaining a representative jury); Carter v. Jury Comm'n, 396 U.S. 320,330 (1970) (noting that the exclusion of blacks "contravenes the very idea of a jury- a body truly representative of the community" ") (quoting Smith v. Texas, 311 U.S. 128, 130 (1940)); Brown v. Allen, 344 U.S. 443, 474 (1953) (requiring that jury lists "reasonably reflect[ ] a cross-section of the population suitable in character and intelligence for that civic duty"); Glasser v. United States, 315 U.S. 60,85 (1942) (concluding that the notions "of what a proper jury is have developed in harmony with our basic concepts of a democratic society and a representative government"); Strauder v. West Virginia, 100 U.S. 303, 308 (1880) (finding the "very idea of a jury" to be "a body of men composed of the peers or equals of the person whose rights it is selected or summoned to determine . . of his neighbors, fellows, associates"). 
the selection of jurors by any method other than a process which will insure a trial by a representative group are undermining processes weakening the institution of jury trial, and should be sturdily resisted. ${ }^{13}$

Similarly, a unanimous Supreme Court announced in Smith v. Texas that "[i]t is part of the established tradition in the use of juries as instruments of public justice that the jury be a body truly representative of the community."14 Moreover, the Court held that a system resulting in "the exclusion from jury service of otherwise qualified groups not only violates our Constitution and the laws enacted under it but is at war with our basic concepts of a democratic society and a representative government." 15

Six years after Smith, the Supreme Court reiterated its dedication to representative juries in Thiel v. Southern Pacific Co.:

The American tradition of trial by jury ... necessarily contemplates an impartial jury drawn from a cross-section of the community. This does not mean, of course, that every jury must contain representatives of all the economic, social, religious, racial, political and geographical groups of the community; frequently such complete representation would be impossible. But it does mean that prospective jurors shall be selected by court officials without systematic and intentional exclusion of any of these groups. Recognition must be given to the fact that those eligible for jury service are to be found in every stratum of society. Jury competence is an individual rather than a group or class matter. That fact lies at the very heart of the jury system. To disregard it is to open the door to class distinctions and discriminations which are abhorrent to the democratic ideals of trial by jury. ${ }^{16}$

In numerous jury-related decisions, the ability to preserve representativeness has been the dispositive issue. For example, the Supreme Court has construed the Sixth Amendment to prohibit the exclusion of cognizable groups from juries based on the serious threat such exclusion would pose to representativesness. ${ }^{17}$ Likewise, the Court has held that the Sixth Amendment allows juries with fewer than twelve members, ${ }^{18}$ and permits juries to return less than unanimous verdicts, ${ }^{19}$ because the relative threat to representativeness seems minimal.

13. 315 U.S. at 86 (citation omitted).

14. Smith v. Texas, 311 U.S. 128, 130 (1940) (reversing black defendant's conviction on equal protection grounds where his indictment was ordered by a grand jury from which blacks were intentionally and systematically excluded).

15. Id. (citation omitted).

16. 328 U.S. 217, 220, 223-24 (1946) (citations omitted) (barring jury selection discrimination "against persons of low economic and social status").

17. Carter v. Jury Comm'n, 396 U.S. 320, 330 (1970) (striking down a jury selection system that diminished representativeness by excluding a cognizable group from jury service, "contraven[ing] ... the very idea of a jury").

18. Williams v. Florida, 399 U.S. 78, 102 (1970) (allowing 6-person state jury, because "the concern that the cross-section will be significantly diminished ... [is] an unrealistic one" if "arbitrary exclusions of a particular class from the jury rolls are forbidden").

19. Apodaca v. Oregon, 406 U.S. 404,410 (1972) (upholding a less-than-unanimous jury verdict because the Sixth Amendment's mandate for a representative cross-section does not require unanimity). 
Commensurate with these decisions, the Supreme Court has developed a set of jury selection principles to further the goal of representativeness. ${ }^{20}$ Under this model, fairness depends on the aggregate composition-the impartialityof juries. Thus, the Court's goal can be achieved through reference only to the rights of defendants, without considering the rights of the individual jurors. The rules under this model ensure that lists of potential jurors-the jury pools-include a fair cross-section of the community from which no cognizable groups have been systematically excluded. ${ }^{21}$ Defendants can challenge convictions where irregularities in the jury selection process impact the fair cross-section. ${ }^{22}$ While litigants and parties have no right to a representative jury per se, they do have the right to a jury selection system that guarantees a fair possibility of a representative jury. ${ }^{23}$ However, as long as the overall jury selection system meets the requirements of the Sixth Amendment, an individual who believes that she has been barred from service on an impermissible basis, such as race or sex, cannot protest her exclusion.

The representativeness model can only partially safeguard the rights of prospective jurors. In Holland v. Illinois, a white defendant argued that the prosecutor's use of peremptories to strike all the black prospective jurors on the basis of race violated the Sixth Amendment by depriving him of a "fair possibility" that the petit jury would represent a cross-section of the community. ${ }^{24}$ Although the Court held that the defendant had standing to raise this Sixth Amendment challenge, it rejected his argument that the fair cross-section requirement extends beyond assembling the venire. ${ }^{25}$ The Court concluded that the traditional understanding of representativeness "has never included the notion that, in the process of drawing the jury, that initial representativeness cannot be diminished by allowing both the accused and the State to eliminate persons thought to be inclined against their interests-which is precisely how the traditional peremptory-challenge system operates." 26 Writing for the Court, Justice Scalia concluded that the "Sixth Amendment requirement of a fair cross section on the venire is a means of assuring, not a representative jury (which the Constitution does not demand), but an impartial one (which it does)."27

20. See Taylor v. Louisiana, 419 U.S. 522, 538 (1975).

21. See id.

22. See Holland v. Illinois, 493 U.S. 474, 477 (1990).

23. See id. at 480; see also Thiel v. Southern Pac. Co., 328 U.S. 217, 223 (1946) (stating that the right to an impartial jury does not include the right to any particular aggregate composition of the jury).

24. 493 U.S. at 478.

25. Id. (concluding that statements in earlier cases alluding to a requirement of a "fair possibility" of a representative jury did not require more than the "inclusion of all cognizable groups in the venire," and that a "prohibition upon the exclusion of cognizable groups through peremptory challenges has no conceivable basis in the text of the Sixth Amendment ....").

26. Id. at 480 .

27. Id. at 480-81. Justice Scalia's differentiation between impartiality and representativeness is irrelevant to the issues discussed herein. Regardless of the label used for this normative ideal, the same jury selection principles apply. Thus, for prospective jurors, the Sixth Amendment provides only limited protection commensurate with the rights of criminal defendants in selecting their juries. But see id. at 514 (Stevens, J., dissenting) (arguing that "[a] reasonably representative jury pool . . . is not the ultimate goal of the Sixth Amendment," and that the state may "never arbitrarily remove jurors on a discriminatory basis unrelated to their ability to serve as jurors"). 
Holland placed the right of jury selection squarely with the defendant. Moreover, the Court confirmed that these Sixth Amendment guarantees apply solely to the venire stage of jury selection. Once the venire has been assembled, the Sixth Amendment affords prospective jurors no protection against discrimination on the basis of race or sex. The Supreme Court's failure to extend the fair cross-section requirement to petit juries had little impact upon those excluded on the basis of race, because the Court had already granted significant constitutional protection of their jury right at the peremptory challenge stage. ${ }^{28}$ Because the Court did not erect a parallel structure for women until recently, any protection that prospective women jurors gleaned from the Sixth Amendment at the venire stage faced nullification at the voir dire stage through the exercise of sex-based peremptory challenges.

\section{B. The Rights of Citizenship}

Historically, the jury has served a second, equally important function. As an instrument of self-governance, juries enable citizens to participate in public life. ${ }^{29}$ Moreover, citizen-based decisionmaking is particularly important in the criminal justice system when the state imposes punishment on an individual. ${ }^{30}$ More than any other civic institution, "the jury has been the symbol of a democratic people zealous of freedom and afraid of centralized government

28. See Batson v. Kentucky, 476 U.S. 79 (1986).

29. See John P. Dawson, A History of Lay Judges 10 (1960) (quoting Plato, who wrote about participation in jury trials in his text entitled Laws that "all should have a share, for he who has no share in the administration of justice is apt to imagine that he has no share in the state at all"); HARRY Kalven, JR. \& Hans Zeisel, The American Jury 3, 7 (1966) (commenting that the American jury "provides an important civic experience for the citizen"); Broeder, supra note S, at 419 ("Jury service fumishes the only means, other than by voting, through which the citizen can actually participate in the administration of government. Service on a jury gives one a sense of community responsibility. It acquaints the citizen with justice as it is practically administered."); Harry Kalven, Jr., The Dignity of the Civil Jury, 50 VA. L. Rev. 1055, 1062 (1964) (stating that "the jury provides an important civic experience for the citizen.... The heart of the matter, the trial itself and the deliberation, is very often a major and moving experience in the life of the citizen-juror."); Drew L. Kershen, Vicinage, 30 OKLA. L. REv. 1, 83 (1977) ("As Thomas Jefferson stated, participation of the ordinary citizen on a jury permits a democratic element to be preserved in the administration of justice by the judicial branch of government."); Toni M. Massaro, Peremptories of Peers?-Rethinking Sixth Amendment Doctrine, Images, and Procedures, 64 N.C. L. Rev. 501, 512-15 (1986) (arguing that jury trials are important to a democracy because they educate citizens about the justice system, give them the responsibility for the quality of government, and increase jurors' respect for judgments, all of which helps to preserve government power); see also Grace Elizabeth Woodall Taylor, Jury Service for Women, 12 U. FLA. L. REv. 224, 231 (1959) (quoting former Chief Justice Harlan Stone ("Jury service is one of the highest duties of citizenship, for by it the citizen participates in the administration of justice between man and man between government and the individual."), 37 KAPPA BETA PI Q. 15 (1959)). One English judge, Lord Justice Patrick Devlin, remarked that "[e]ach jury is a little parliament. ... The first object of any tyrant in Whitehall would be to make Parliament utterly subservient to his will; and the next to overthrow or diminish trial by jury, for no tyrant could afford to leave a subject's freedom in the hands of twelve of his countrymen." Jon M. Van Dyke, Jury Selection Procedures: Our Uncertain Commitment to Representattve Panels 8 (1977).

30. See Taylor v. Louisiana, 419 U.S. 522, 530 (1975) (declaring that "[t]he purpose of a jury is to guard against the exercise of arbitrary power-to make available the commonsense judgment of the community as a hedge against the overzealous or mistaken prosecutor and in preference to the professional or perhaps overconditioned or biased response of a judge"); THE FEDERALIST No. 83, at 464 (Alexander Hamilton) (Isaac Kramnick ed., 1987) (arguing that the jury serves as "a valuable safeguard to liberty" and as "the very palladium of free government"). 
power." 31 Furthermore, the jury may be the only governmental function in which many citizens still play a direct role. ${ }^{32}$ Jury service thus educates citizens about politics, law, and civic institutions, ${ }^{33}$ making the equal opportunity to sit on a jury an important element of full citizenship. In order to preserve this citizenship-affirming function, jury selection principles must reflect the interests of those excluded as well as those included.

In Powers $v$. Ohio, the Supreme Court recently reaffirmed its belief in the important citizenship function served by juries. ${ }^{34}$ The Court emphasized the value of jury service as a symbol of democratic participation and full citizenship. ${ }^{35}$ Moreover, the Court acknowledged that the opportunity for that participation has "long been recognized as one of the principal justifications for retaining the jury system." 36 Finally, the Court noted that, "with the exception of voting, for most citizens the honor and privilege of jury duty is their most significant opportunity to participate in the democratic process." ${ }^{37}$ The Powers Court quoted Alexis de Tocqueville, who stated that

the institution of the jury raises the people itself, or at least a class of citizens, to the bench of judges ... [and] invests the people, or that class of citizens, with the direction of society.... The jury ... invests each citizen with a kind of magistracy; it makes them all feel the duties which they are bound to discharge towards society, and the part which they take in its government. ${ }^{38}$

Precisely because jury service provides an opportunity for citizens to participate in government, the right to serve has been a critical goal in the broader struggles of both minorities and women to gain equality. ${ }^{39}$ Advocates for a variety of groups have long recognized the importance of jury service as an essential right of citizenship:

Jury service is one of the few ways in which citizens can participate directly in the governmental process. It provides an opportunity for an individual to absorb the values of the American legal system and become involved as a citizen responsible for the welfare and just treatment of other citizens. The denial or restriction of this opportunity to participate is a denial of the full experience of citizenship. 40

31. Broeder, supra note 5, at 386.

32. Tom C. Clark, The American Jury: A Justification, in Selected Readings: The JuRY 1,7 (Glenn R. Winters ed., 1971); see also Powers v. Ohio, 499 U.S. 400, 402 (1991).

33. Powers v. Ohio, 499 U.S. 400, 406-07 (1991).

34. Id. at $402,406-08$.

35. Id.

36. Id. at 406 (citing Duncan v. Louisiana, 391 U.S. 145, 147-58 (1968)).

37. Id. at 407.

38. Id. (quoting 1 Alexis de Toceveville, Democracy in AMERICA 61-62 (Century Co. 1898) (1835) (footnote omitted)).

39. See Eleanor Flexner, Century of Struggle: The Woman's Rights Movement in the UNITED STATES 164 (rev. ed. 1975) (1959) (describing jury duty as "one of the most basic demands voiced by women"). For a more comprehensive discussion of this point, see text accompanying notes 144-166 infra.

40. Anne Rankin Mahoney, Women Jurors: Sexism in Jury Selection, in Women, Tre CourTs, aNd EqualtTy 208, 208 (Laura L. Crites \& Winifred L. Hepperle eds., 1987). 
In evaluating the constitutionality of jury selection schemes, the Supreme Court has explicitly recognized jury service as essential to citizenship. For example, in a challenge to a jury selection system that effectively excluded daily wage earners, and thus appeared to privilege wealthy citizens, the Court emphasized that "[j]ury service is a duty as well as a privilege of citizenship ... . Thus a blanket exclusion of all daily wage earners, however well-intentioned and however justified by prior actions of trial judges, must be counted among those tendencies which undermine and weaken the institution of the jury trial."41 The representativeness model suggests that the exclusion of classes of prospective jurors only harms the factfinding ability of the jury. Yet exclusion also harms prospective jurors themselves, by denying them one of the most basic rights of citizenship solely on the basis of their membership in a cognizable group. Therefore, to protect the participatory function of the jury, the legal system must prohibit the exclusion of jurors from jury service based on group status.

\section{Sex-Based Peremptory Challenges: A Rights-Based Analysis of JURY SERVICE}

Judicial decisions invalidating racial discrimination in jury selection recognized over the course of a century both that defendants have a right to an impartial jury and that prospective jurors have a right to serve. By contrast, decisions over the same period involving jury discrimination based on sex never acknowledged a comparable right of participation for women. The disparate treatment of race and sex in jury selection persisted until recently. The Supreme Court barred race-based peremptory challenges because they implicate prospective jurors' rights to participate in society as full citizens, and, as of 1994, barred those based on sex as well. This Part discusses the use of peremptory challenges and traces the development of the Supreme Court's approach to racial and sexual discrimination in jury selection, revealing at least one explanation for the longstanding inconsistency. The different treatment accorded to race and sex in the context of jury selection reveals the basic assumption by courts that blacks were excluded as unfit, while women have been excluded for other, allegedly benign reasons. As a result of this misperception, cases involving jury rights of blacks reflected an attempt to remedy a seeming injustice, while similar cases involving the rights of women lacked this remedial concern.

\section{A. Peremptory Challenges}

Peremptory challenges are only one step in the process of selecting a jury. The first step involves creating a jury pool comprised of citizens who meet statutory qualification requirements. ${ }^{42}$ The pool can be assembled in a variety of ways, often from voter registration lists, driver's license registrations, or

41. Thiel v. Southem Pac. Co., 328 U.S. 217, 224 (1946) (citing Glasser v. United States, 315 U.S. 60, 86 (1942)).

42. James J. Gobert \& Walter E. Jordan, JuRy Selection: The Law, Art, and Science of Selecting a JuRY 147-52 (2d ed. 1990). 
telephone directories. From that pool, a jury commissioner or designated official uses an approved method, such as a master jury wheel, and calls a random sample of several hundred prospective jurors. ${ }^{43}$ The randomness, usually required by statute, aims to ensure that no identifiable group can be excluded from the selection process, and to provide every individual in the jury pool with an equal chance to be called. ${ }^{44}$

Once this group-the venire-has been assembled, the qualification process begins. Often, the jury commissioner mails selected prospective jurors a pretrial questionnaire to determine their willingness to serve and whether any are subject to exemptions or excuses. ${ }^{45}$ A personal interview may also follow. At this point, the final jury selection process-voir dire-begins, when the judge and counsel on both sides whittle the venire down to a group of twelve. ${ }^{46}$ Lawyers question prospective jurors to determine whether to ask the judge to remove them "for cause." Challenges for cause allow attorneys to strike jurors who seem unable to deliberate impartially. ${ }^{47}$ For example, either lawyer can strike a prospective juror with a for-cause challenge if that juror is related by blood or marriage to a party or her attorney, has a friendship or business relationship with a party or her attorney, possesses independent knowledge of the facts, or has a preconceived opinion about the merits of the case. ${ }^{48}$

The art of jury selection depends not only on identifying jurors likely to be partial, but, more importantly, on demonstrating to the court a juror's lack of impartiality. ${ }^{49}$ Given the frequent difficulty of establishing bias, the for-cause challenge is an imperfect way to eliminate biased jurors. ${ }^{50}$ Even a prospective juror who admits that she has already formed an opinion about the case may survive a for-cause challenge by convincing the court she is nonetheless unbiased. $^{51}$ Thus, the peremptory challenge provides parties with a final opportunity to strike biased jurors.

Peremptory challenges allow the striking party to excuse a prospective juror for almost any reason. Traditionally, each party is granted a limited number of peremptory challenges. ${ }^{52}$ Unlike for-cause challenges, peremptory challenges

43. Id. at 150-52.

44. GOBERT \& JoRDAN, supra note 42 , at $149-50,158-60$.

45. Id. at 151-52, 155-58.

46. Barbara A. Babcock, Voir Dire: Preserving "Its Wonderful Power," 27 STAN. L. Rev. 545 (1975).

47. Swain v. Alabama, 380 U.S. 202, 220 (1965) (noting that "challenges for cause permit rejection of jurors on a narrowly specified, provable and legally cognizable basis of partiality"), overruled on other grounds by Batson v. Kentucky, 476 U.S. 79 (1986).

48. See GoBert \& JORDAN, supra note 42, at 199-200; VAN DYKE, supra note 29, at 14.

49. GOBERT \& JORDAN, supra note 42 , at 194.

50. The Supreme Court has recognized the shortcomings of the for-cause challenge:

Experience has shown that one of the most effective means to free the jury-box from men unfit to be there is the exercise of the peremptory challenge. The public prosecutor may have the strongest reasons to distrust the character of a juror offered, from his habits and associations, and yet find it difficult to formulate and sustain a legal objection to him.

Hayes v. Missouri, 120 U.S. 68, 70 (1887).

51. Babcock, supra note 46 , at 550 .

52. In federal capital cases, the prosecution and defense each get 20 peremptory challenges. In noncapital felony cases, the defendant receives 10 peremptory challenges, while the prosecution only gets six. In federal misdemeanor cases, each side receives three. FED. R. CRIM. P. 24(b). In state 
need not have an articulable basis. Both parties may remove jurors "without a reason stated, without inquiry and without being subject to the court's control."53

Undeniably, group stereotypes-based on race, gender, religion, economic status, or education-often motivate the use of peremptory challenges. ${ }^{54}$ The system allows "the covert expression of what we dare not say but know is true more often than not."5s However, camouflaging invidious reasons for exclusion means little if the true harm of exclusion is the denial of an equal right to serve on juries, rather than the creation of painful feelings of inferiority.

Although peremptory challenges are not expressly provided for in the Constitution, ${ }^{56}$ they are deeply rooted in our legal system. The Court has called the exercise of peremptory challenges "one of the most important of the rights secured to the accused." 57 But despite the venerable status of peremptory challenges in the American legal system, their shortcomings have precipitated an extensive constitutional reexamination in the past eight years, as the next Part demonstrates.

\section{B. The Diverging Doctrines of Discriminatory Jury Selection}

In 1986, the Supreme Court held in Batson v. Kentucky that a criminal defendant's equal protection rights are violated when a prosecutor exercises race-based peremptory challenges to exclude prospective jurors of the criminal defendant's race. ${ }^{58}$ Six years after Batson, the Court extended the prohibition on the discriminatory exercise of peremptory challenges to civil litigants in Edmonson v. Leesville Concrete Co. ${ }^{59}$ The same Term the Court eliminated

courts, state statutes define the number of peremptory challenges available to the parties. See VAN DYKE, supra note 29, at 157.

53. Swain v. Alabama, 380 U.S. 202, 220 (1965); see also Michael J. Saks \& Reid Hastie, Soctal Psychology in COURT 54 (1978) (describing peremptory challenges before the development of scientific jury selection techniques as merely "hunches, unsystematic past experience, intuition, [or] stabs in the dark").

54. See, e.g., HANS \& VIDMAR, supra note 6, at 73 (discussing the use of stereotypes in peremptory challenges and citing the example that defense attomeys look for jurors whose occupations expose them to "a wide variety of experiences," on the assumption that these jurors will be "likelier to forgive indiscretions in others"); VAN DYKE, supra note 29, at 152 (explaining that prosecutors generally believe that prospective jurors who are white, middle-aged, and middle-class are likely to side with the government).

55. Babcock, supra note 46 , at 554 .

56. In Stilson v. United States, 250 U.S. 583, 586 (1919), the Supreme Court declined to incorporate the peremptory challenge into the Sixth Amendment right to an impartial jury, a decision that has inspired much criticism.

57. Pointer v. United States, 151 U.S. 396, 408 (1894). In fact, the Supreme Court considers peremptory challenges so important that their denial or impairment constitutes reversible error, even without any showing of prejudice. See Swain v. Alabama, 380 U.S. 202, 219 (1965); Gulf, Colo. \& Santa Fe R.R. v. Shane, 157 U.S. 348, 351 (1895). But see Ross v. Okla., 487 U.S. 81 (1988) (finding no reversible error where defendant was required to exercise one of his peremptory challenges to remove a juror who should have been removed for cause).

58. 476 U.S. 79 (1986).

59. 500 U.S. 614 (1991). The primary issue in Edmonson was whether civil litigants constituted state actors. Once that hurdle was cleared, there was no reason not to apply Batson, as the discriminatory exercise of peremptories had the same effect on prospective jurors in the civil context as in the criminal context. Id. at 631 . 
Batson's implicit requirement that a criminal defendant share the excluded juror's race in Powers v. Ohio, holding that any defendant could assert a claim that race-based peremptory challenges violated the equal protection rights of the excluded jurors. ${ }^{60}$ Finally, in Georgia ${ }^{\prime} v$. McCollum, the Court extended Batson even further, to prohibit criminal defendants from exercising race-based peremptory challenges. ${ }^{61}$

The Batson decision inspired another question: whether sex-based peremptory challenges are equally unconstitutional. Until the Supreme Court resolved the question this year, no clear consensus had emerged among the courts that had addressed this issue. ${ }^{62}$ At the federal level, only the Ninth Circuit extended Batson to sex, ${ }^{63}$ while several other circuits affirmed the continued use of sexbased peremptory challenges. ${ }^{64}$ Similarly, state courts faced with the issue declined the invitation to extend Batson to sex. A majority of these courts, however, did not even address the issue of women's jury rights. ${ }^{65}$ Instead, these courts based their decisions on a finding that the challenged jurors were men, who lack a history of group discrimination; a belief that because the defendant was male, he did not have standing to challenge the use of peremptory challenges against women; a determination that the Supreme Court's failure in Batson to include sex in its categorical ban evidenced its intent not to include it; or a conclusion that the respective histories of discrimination against blacks and women are not similar enough to warrant similar treatment. Conversely, those cases that extended Batson to sex went farther toward recharacterizing the basic

60. 499 U.S. 400,415 (1991).

61. 112 S. Ct. 2348, 2356 (1992). Interestingly, during oral arguments in this case, Justice Kennedy asked the state's counsel whether he was suggesting "that gender stereotypes are more valid than race stereotypes." Counsel responded, "No. There has been a particular problem with invidious race discrimination, and there has not been a similar problem with gender discrimination. The court has to draw the line somewhere if it is going to preserve the institution of peremptory challenges." Arguments Heard in Georgia v. McCullum, reprinted in 50 CRIM. L. REP. (BNA) 3182, 3183 (Mar. 4, 1992).

62. See J.E.B. v. T.B., 114 S. Ct. 1419 (1994). Legal commentators also disputed whether sexbased peremptory challenges are constitutional. See e.g., Shirley S. Sagawa, Batson v. Kentucky: Will it Keep Women on the Jury?, 3 BERKELEY WoMEN's L.J. 14, 48 (1987) (concluding that gender-based peremptories should be prohibited because of their "negative effects to women, to defendants, and to the entire community"); Note, Beyond Batson: Eliminating Gender-Based Peremptory Challenges, 105 HARV. L. REv. 1920 (1992) (arguing that gender-based peremptories derive from historical discrimination against women and violate the equal protection rights of the excluded women).

63. United States v. De Gross, 960 F.2d 1433, 1439 (9th Cir, 1992) (en banc).

64. For a sampling of those that refused to extend Batson, see, for example, United States v. Broussard, 987 F.2d 215 (5th Cir. 1993); United States v. Nichols, 937 F.2d 1257 (7th Cir. 1991), cert. denied, 112 S. Ct. 989 (1992); United States v. Hamilton, 850 F.2d 1038 (4th Cir. 1988), cert. denied, 493 U.S. 1069 (1990).

65. E.g., Daniels v. State, 581 So. 2d 536 (Ala. Crim. App. 1990) (holding that the court had no authority to extend Batson to sex), cert. denied, 112 S. Ct. 315 (1991); Hannan v. Commonwealth, 774 S.W.2d 462 (Ky. Ct. App. 1989) (holding that Batson did not authorize the extension of its principles beyond racial discrimination); State v. Adams, 533 So. 2d 1060 (La. Ct. App. 1988) (holding that a female defendant was not denied equal protection by the state's purposeful peremptory strikes of all men on the venire), cert. denied, 540 So. 2 d 338 (La. 1989); State v. Pullen, 811 S.W.2d 463 (Mo. Ct. App. 1991) (holding that Batson applies only to race-based, not sex-based, discrimination, despite the court's belief that no real distinction exists between the two types of discrimination that would make one less offensive than the other). 
issue as whether prospective jurors have an independent right not to be excluded from juries on the basis of sex. ${ }^{66}$

J.E.B. v. T.B. resolved the technical question of Batson's application to sex. The petitioner, a defendant to paternity and child support claims, protested the State's use of peremptory challenges to remove nine men from the panel, resulting in an all-female jury. ${ }^{67}$ On the narrowest level, the Court corrected the doctrinal divergence between courts' treatment of race- and sex-based peremptory challenges by holding that the intentional exclusion of men from the jury violates the Equal Protection Clause. More broadly, though, as the next Part demonstrates, the Court expanded the analytical framework for analyzing all jury exclusion questions by acknowledging that "[d]iscrimination in jury selection, whether based on race or on gender, causes harm to the litigants, the community, and the individual jurors who are wrongfully excluded in the judicial process." 68

\section{Black jurors: personal rights and the citizenship model.}

The exclusion of blacks from juries is a useful starting point for any rightsbased analysis of jury service. For black prospective jurors, the removal of various barriers to jury service has been driven, at least in part, by a concern for the prospective jurors' rights. At the outset, courts and commentators realized that denial of a fundamental element of citizenship on the basis of race stigmatizes the individual. This recognition affected a series of jury selection cases spanning more than one hundred years and culminating in Batson.

In an 1880 case, Strauder v. West Virginia, the Supreme Court struck down a West Virginia law which excluded blacks from jury pools. ${ }^{69}$ The Court based its holding on the equal protection rights of the defendant. ${ }^{70}$ However, the Court recognized in dicta that the exclusionary law also affected prospective jurors, since "[t]he very fact that colored people are singled out and expressly

66. In several instances, however, state courts have relied on state law-either constitutional or statutory equal rights provisions-to prohibit sex-based peremptory challenges, thereby insulating their decisions from Supreme Court review. What is noteworthy about these decisions, beyond their common rhetoric about the Supreme Court's intent with respect to the scope of Batson, is that, in contrast to Batson, they consider and rely on the rights of excluded jurors. See, e.g., State v. Levinson, 71 Haw. 492,795 P.2d 845, 849 (Haw. 1990) (holding that "the right to serve on a jury is a privilege of citizenship, guaranteed by [Hawaii's] constitution, and provided for by statute, and that, under [Hawaii's] constitution, that right cannot be taken away for any of the prohibited bases of race, religion, sex or ancestry"); Tyler v. State, 330 Md. 261, 623 A.2d 648 (Md. Ct. App. 1993) (holding that because sex is a suspect classification under the state's equal rights amendment, sex-based peremptory challenges are governed by the same rules as race-based exclusions under Batson); New York v. Irizarry, 560 N.Y.S.2d 279, 165 A.D.2d 715 (N.Y. App. Div. 1990) (holding that Batson applies to "the improper use of peremptory challenges to exclude women from a petit jury").

67. 114 S. Ct. 1419, 1421 (1994). The petitioner objected to the State's use of peremptory challenges on the ground that they were exercised solely on the basis of sex, arguing that the logic of Batson v. Kentucky, 476 U.S. 79 (1986), forbids intentional discrimination on that basis. Relying on Alabama precedent, see, e.g., Murphy v. State, 596 So. 2 d 42 (Ala. Crim. App. 1991), cert. denied, 113 S. Ct. 86 (1992), the state court rejected his Batson claim and empaneled the jury. The jury found the petitioner to be the father and the court held him liable for child support.

68. Id. at 1427 (emphasis added).

69. 100 U.S. 303 (1880).

70. Id. at 308 . 
denied [the right to serve as jurors] is practically a brand upon them, an assertion of their inferiority affixed by the law, and a stimulant to that race prejudice which is an impediment to securing . . . equal justice."71

Courts and commentators have most often quoted this passage from Strauder, rather than its narrow holding. A long line of cases following Strauder reflected the Court's awareness of the harm inflicted on potential jurors by race-based exclusions from jury service. ${ }^{72}$ In Carter v. Jury Commission of Greene County, for example, the Court stated that race-based exclusions constitute invidious discrimination because of their stigmatizing effect: "Whether jury service be deemed a right, a privilege, or a duty, the State may no more extend it to some of its citizens and deny it to others on racial grounds than it may invidiously discriminate in the offering and withholding of the elective franchise."73

Two years later, in Peters $v$. Kiff, the Court reversed the criminal conviction of a white defendant from whose jury blacks had been systematically excluded, explaining that, "the exclusion of Negroes from jury service injures not only defendants, but also other members of the excluded class." 74 Exclusion, the court claimed, "stigmatizes the whole class, even those who do not wish to participate, by declaring them unfit for jury service."75

Finally, in Batson, the Court held explicitly that a prosecutor's use of racebased peremptory challenges violated the Equal Protection Clause. ${ }^{76}$ The Court's opinion echoed the spirit of Strauder, explaining that "[a]s long ago as Strauder ... the Court recognized that by denying a person participation in jury service on account of his race, the State unconstitutionally discriminated against the excluded juror."77 Although Batson primarily reflected a concern with the harm to a defendant tried by a jury from which members of his race have been purposely excluded, a subsequent case, Powers v. Ohio, interpreted Batson to "recognize that a prosecutor's discriminatory use of peremptory challenges harms the excluded jurors and the community at large."78 Ultimately, Batson and its progeny effectively constitutionalized the right of prospective jurors not to suffer race-based exclusions, a right first hinted at over a century earlier in Strauder.

71. Id.

72. See, e.g., Carter v. Jury Comm'n, 396 U.S. 320 (1970); Eubanks v. Louisiana, 356 U.S. 584 (1958); Smith v. Texas, 311 U.S. 128 (1940); Norris v. Alabama, 294 U.S. 587 (1935) (finding a violation of the Fourteenth Amendment where the state's jury lists contained the names of blacks but none were ever called for service); Rogers v. Alabama, 192 U.S. 226 (1904); Neal v. Delaware, 103 U.S. 370 (1880).

73. 396 U.S. at 330 .

74. 407 U.S. 493,499 (1972).

75. Id. (emphasis added) (citation omitted).

76. 476 U.S. 79 (1986). The Supreme Court had reached the same conclusion 21 years earlier in Swain v. Alabama, 380 U.S. 202, 203-04 (1965). However, that decision had limited impact, because the Court placed an impossibly strict evidentiary burden on a defendant objecting to a prosecutor's use of a peremptory challenge.

77. Id. at 87.

78. 499 U.S. 400,406 (1991). 
2. Women jurors: derivative rights.

Although the 1880 Supreme Court championed the right of blacks to be free from the stigma of race-based jury exclusion, it continued for almost another century to permit states to confine jury service to men. Only in 1975 did the Court finally rule that the exclusion of women from juries raised a constitutional issue. ${ }^{79}$ Even then, though, the Court analyzed women's jury rights differently from those of blacks, notwithstanding historical evidence that the exclusion of both classes of jurors stemmed from the same motivation-a belief that each group, as a class, was unfit for jury service.

Taylor v. Louisiana was the first Supreme Court opinion imposing constitutional limitations on the exclusion of women from juries. The Taylor Court held that a jury selection system that systematically excluded women violated the fair cross-section requirement. Notably, the Court evaluated the sex-based system strictly in terms of the defendant's rights, failing even to acknowledge the harm inflicted upon the excluded female jurors, much less to base its holding on that harm. Other courts and social theorists addressing the issue of women and juries have taken a similar approach by assuming that the rights of defendants and the courts' need for jurors determines the full extent of women's right to serve on juries. ${ }^{80}$

By adopting such a defendant-centered perspective, Taylor merely echoed Ballard v. United States, which declared women eligible for federal jury service in federal courts sitting in states that allowed women to serve on the same terms as men based on a similar analysis. ${ }^{81}$ The Ballard Court discussed at great length the injury incurred by the defendant through the systematic exclusion of women from the jury. The decision also addressed other injuries: to "the law as an institution, to the community at large, and to the democratic ideal reflected in the processes of our courts." 82 It never mentioned, however, the harm inflicted on the excluded women themselves.

One year after Ballard, the Court upheld New York's jury selection system, which automatically exempted women from jury service unless they took affirmative steps to register for service. ${ }^{83}$ The Court found that the presence of women on state juries stems from "a changing view of women in our public

79. Taylor v. Lousiana, 419 U.S. 522 (1975).

80. See, e.g., People v. Wheeler, 22 Cal. 3d 258, 276, 583 P.2d 748, 761 (1978); cf. Wallace M. Rudolph, Women on the Jury-Voluntary or Compulsory, in SELECTEd REAdings, supra note 32, at 100 (concluding that "there would be no necessity for compulsory service of women on juries if their presence did not add something to the adjudicative process"); Elizabeth M. Sheridan, Women and Jury Service, 11 A.B.A. J. 792, 797 (1925) (concluding that the presence of women "widens the choice and enlarges the number of eligibles so that a better class of jurors are available"); see also R. Justin Miller, The Woman Juror, 2 OR. L. REv. 30, 36 (1922) (finding that legislatures exceed their power to prescribe juror qualifications by the "passing of laws which strike at the institution of the jury itself or which break down some of the safeguards of faimess and impartiality which have been built up thereabout"). But see Healy v. Edwards, 363 F. Supp. 1110 (E.D. La. 1973) (expressing concern that an affirmative registration requirement denies equal protection to potential jurors, but finding that nonlitigants lack standing to raise this issue).

81. 329 U.S. 187 (1946).

82. Id. at 195 .

83. Fay v. New York, 332 U.S. 261 (1947). 
life" and their perceived contribution to impartial deliberation, rather than from a constitutional right to equal status. ${ }^{84}$ This same emphasis on the concept of representativeness - to the exclusion of citizenship-is even seen in one state case prohibiting sex-based peremptory challenges on fair cross-section grounds:

[W] hen a party presumes that certain jurors are biased merely because they are members of an identifiable group distinguished on racial, religious, ethnic, or similar grounds ... and peremptorily strikes all such persons for that reason alone, he not only upsets the demographic balance of the venire but frustrates the primary purpose of the representative cross-section requirement . . . to achieve an overall impartiality by allowing the interaction of the diverse beliefs and values the jurors bring from their group experiences. 85

In other contexts, the Supreme Court's dissimilar treatment of similar cases involving sex or race further supports the proposition that the Court has historically viewed the two types of exclusions differently. ${ }^{86}$ In Patton $v$. Mississippi, the Court relied on statistical evidence in holding that "[w]hen a jury selection plan, whatever it is, operates in such a way as always to result in the complete and long-continued exclusion of any representative at all from a large group of Negroes, or any other racial group, indictments and verdicts . . . cannot stand."87 But in Hoyt $v$. Florida, where the validity of automatic exemptions for women was at issue, the Court was presented with convincing evidence that the exemptions created a similar de facto system of absolute exclusion of women. ${ }^{88}$ The Court, however, refused to find harm despite the statistical similarities to Patton. Instead, it found that statistics showing that disproportionately fewer women volunteers were placed on jury lists were insufficient to prove a violation of the defendant's rights. ${ }^{89}$

84. Id. at 290. For an unusual case acknowledging the rights of the excluded women jurors, see White v. Crook, 251 F. Supp. 401, 408-09 (M.D. Ala. 1966) (three judge court), where the court declared a blanket statutory exclusion of women from juries unconstitutional. The court reasoned that "jury service on the part of the citizens of the United States is considered under our law in this country as one of the basic rights and obligations of citizenship," and that "[j]ury service is a form of participation in the processes of government, a responsibility and a right that should be shared by all citizens, regardless of sex." Id. at 408. The Crook court distinguished Hoyt v. Florida and Fay v. New York, because the defendants in both cases had challenged the exclusion of women through automatic exemptions, whereas in Crook, "the women themselves assert[ed] their right to serve as jurors, or, more accurately, their right not to be excluded from jury service solely because of their sex." Id. at 409 .

85. People v. Wheeler, 22 Cal. 3d 258, 276, 583 P.2d 748, 761 (1978).

86. Compare, e.g., Carter v. Jury Comm'n, 396 U.S. 320, 330 (1970) (involving race) with Taylor v. Louisiana, 419 U.S. 522, 530 (1975) (involving sex).

87. 332 U.S. 463,469 (1947).

88. 368 U.S. 57 (1961). Only 10 of the 10,000 persons on the county jury lists were women, and less than $5 \%$ of the women who had volunteered were placed on the list. Id. at 65,67 . Thus, for all practical purposes,

automatic exemption equal[ed] automatic exclusion. If a state has a statute which requires that a woman volunteer if she wishes to serve on a jury, even if that statute does not purport to exclude women and even if it is fairly administered, the result will probably be that few, if any, women will serve on a jury in that state. Only a small fraction of those eligible ever volunteer.

Diane F. Yockey, Courts, Women Jurors, Automatic Exemption, 36 Tul. L. REv. 858, 861 (1962).

89. Hoyt, 368 U.S. at 64-65, 67-68. But see Eubanks v. Louisiana, 356 U.S. 584 (1958) (holding that the systematic exclusion of blacks from jury lists violates the Fourteenth Amendment). 
The Supreme Court only recently recognized an independent constitutional right of prospective jurors not to be excluded on the basis of sex. In doing so, the Court erected an essential piece of protection for women's jury rights. For prospective jurors need protection at two separate stages of the selection process in order to preserve their opportunity to serve on a jury. First, the jury pool must include the prospective jurors, and second, these potential jurors must survive the peremptory challenge stage of voir dire with the same frequency as other classes of jurors.

When Taylor invalidated one of the most common types of jury selection schemes-affirmative registration requirements-women secured a guarantee that jury pools will include them on approximately the same terms as men. However, the same stereotypes about women's roles and female characteristics that once justified their exclusion from the first stage often resulted in their exclusion from the second. Only by recognizing that the exclusion of venire persons on the basis of sex is as stigmatizing and prejudicial to the excluded juror as those based on race, and extending Batson to sex, could the Court prevent further discrimination from denying women this basic citizenship right.

\section{The Exclusion of Women and the Representativeness Model}

As the review of cases in Part II makes clear, courts facing the issue of the discriminatory exclusion of jurors on the basis of sex have emphasized the ideal of representativeness over the right of citizenship. These cases share a common assumption: Because the basis of exclusion was unfitness in the case of blacks but not for women, only blacks were harmed. And though history belies this assumption, as women were excluded both because of "benign" practical reasons, and because of perceived unfitness, ${ }^{90}$ women reacted to this judicial reasoning by struggling to justify their inclusion on grounds other than equality.

This Part explores the history of this struggle, highlighting the intersection between gender difference analysis and the predominance of the representativeness model in courts' assessments of sex-based exclusion from juries, as well as the structure of arguments made to these courts. Then, it explores the importance of jury service to the women's movement and examines the way its advocates cast arguments for this right - both as citizenship and representativeness issues. Finally, this Part contends that courts accepted only the latter mode of argument. Together with a common perception that women are unfit to serve as jurors, the courts' unwillingness to consider the representativeness analysis inexplicably persisted to the modern day, despite the wide recognition that exclusion from jury service on the basis of membership in a cognizable group is stigmatizing. Only recently did the Court correct this anomally. ${ }^{91}$

90. See text accompanying notes 180-234 infra.

91. J.E.B. v. T.B., 114 S. Ct. 1419 (1994). 


\section{A. The Historical Background}

In the last century, the Supreme Court both acknowledged and responded to the long history of exclusion from juries experienced by blacks. However, despite the fact that women have suffered even greater historical exclusion from juries than blacks, the Supreme Court consistently refused to recognize any citizenship-based right of women to serve. As one comment argues,

The history of judicial treatment of sex based discrimination in jury selection systems reveals that, despite early recognition that jury service is an important aspect of citizenship, jury selection has been an area in which male judges and legislators have been particularly myopic in viewing women's role. Undoubtedly because of the historic importance given to the American jury, women's participation in the institution has been consistently minimized. ${ }^{92}$

The Supreme Court treated women's exclusion from juries as less troublesome than the exclusion of blacks: less common, less stigmatic, and less prejudicial. In fact, even as the Court first recognized a constitutional problem with the exclusion of blacks, it reaffirmed the right of states to exclude women. In Strauder $v$. West Virginia, ${ }^{93}$ the Supreme Court invalidated an 1873 statute limiting jury service to white males, holding that the black defendant had the right to have jurors selected without "discrimination against them."94 Although the Court relied on the defendant's equal protection rights, dicta in the case reflected the Court's deep concern with the rights of the excluded jurors and the effects of exclusion on the dignity of the "negro race."95 Nonetheless, the Court announced that states could constitutionally limit jury pools to men. ${ }^{96}$ Just one year later, the Court decided a second case addressing the exclusion of blacks from jury pools. In Neal $v$. Delaware, the Court held that local officials could not rely on a provision of the state constitution, defining electors as white males, to justify barring from juries blacks who qualified as "electors" through the Fifteenth Amendment. ${ }^{97}$

Thus, even as the Court enabled blacks to overcome major legal obstacles to jury service-the exclusion of blacks from jury selection lists both by state statute and unofficial action-it explicitly left women behind. Even after the passage of the Nineteenth Amendment granting women the right to vote, state

92. Rhonda Copelon, Elizabeth M. Schneider \& Nancy Stearns, Constitutional Perspectives on Sex Discrimination in Jury Selection, Women's RTs. L. ReP., June 1975, at 3, 6.

93. 100 U.S. 303 (1880).

94. Id. at 309.

95. Id. at 306-07; see also Blanche Crozier, Constitutionality of Discrimination Based on Sex, 15 B.U. L. Rev. 723, 729 (1935) (suggesting that Strauder moved "in the direction . . of an increasing emphasis upon the upholding of the dignity and equality, the legal status, of the negro race").

96. 100 U.S. at 310. After Strauder, many state courts affirmed the constitutionality of their sexexclusive regimes against a variety of challenges. E.g., Bacom v. State, 39 So. 2 d 794 (Fla. 1949), cert. denied, 338 U.S. 835 (1949) (due process challenge); Hall v. State, 136 Fla. 644, 187 So. 392 (Fla. 1939) (equal protection challenge); State v. Emery, 224 N.C. 581, 31 S.E.2d 858 (N.C. 1944) (finding women ineligible to serve on juries under state constitution which granted defendant the right to be tried by a jury of "good and lawful men"); McKinney v. State, 3 Wyo. 719, 30 P. 293 (1892) (bypassing the issue of sex discrimination by concluding that only female defendants had standing to object to the jury selection system).

97. 103 U.S. $370,389-92$ (1881). 
courts rejected arguments similar to those made in Neal, and continued to refuse women the right to serve on juries. ${ }^{98}$ Indeed, not until 1975 did the Supreme Court find any constitutional protection for the right of women to serve on juries, when the Court finally held that the Sixth Amendment's fair cross-section requirement mandated that states draw juries from venires in which women are not excluded as a class. ${ }^{99}$

The exclusion of women from juries developed in three stages. At first, state laws excluded women entirely from jury service. Then, many courts divorced jury service from voting, treating the former as a privilege rather than as a right. During the third stage, courts upheld various automatic exemptions for women who were otherwise eligible for jury service. When courts finally struck down these three barriers to women's jury service, they focused solely on the perceived "differences" between men and women. Thus, the courts addressed only the factfinding role of the jury and ignored the female juror's right to participate. Ironically, the focus on gender difference, instrumental in overcoming the total exclusion of women, obscured the harm that an artifact of that discrimination, sex-based peremptory challenges, continued to inflict on women.

\section{Stage one: absolute exclusion.}

At English common law, juries were summoned with a writ of venire facias, ordering the sheriff to bring from his county "twelve free and lawful men, liberos et legales homines." 100 Although "homines" could refer to both sexes, the doctrine of propter defectum sexus-"because not of the male sex" explicitly excluded women. ${ }^{101}$ With few exceptions, common law juries comprised only men. ${ }^{102}$

American common law readily incorporated the total exclusion of women from juries ${ }^{103}$ until 1870 , when the territory of Wyoming ventured to seat the

98. See text accompanying notes $120-123$ infra.

99. Taylor v. Louisiana, 419 U.S. 522, 533 (1975). As late as 1961 , the Court still validated automatic jury service exemptions for women which were based solely on gender. Hoyt v. Florida, 368 U.S. 57, 61-62 (1961).

100. Miller, supra note 80 , at 30.

101. Id; 3 William Blackstone, Commentaries *352, *362.

102. Miller, supra note 80 , at 31 . Cases where the pregnancy of a woman was a disputed fact received special consideration. For example, a woman sentenced to death might claim that she was pregnant in order to stay the execution until after the child was born, or a widow might feign being "herself with child in order to exclude the next heir." $I d$. In such cases, the court would summon a jury of "'twelve matrons or discreet women" to inspect the woman for pregnancy. Id. Even in these cases, however, the women were not trusted to judge the facts by themselves, as the jury also contained 12 men. Although the pregnancy inspection was conducted solely by the women, it occurred in the presence of the men jurors. Id.

103. In England, however, the situation was a bit more progressive. In 1919, England passed the Sex Disqualification Act, which recognized women jurors. $9 \& 10 \mathrm{Geo} .5, \mathrm{ch} .71, \S 1$ (Eng.). The Act prohibited exemption from jury service on the basis of sex alone, but allowed any judge to order that the jury be composed solely of men. Id. at § 1(b). In addition, the Act provided that, upon a woman juror's application, a judge could exempt her based on the nature of the evidence to be presented at trial or the issues to be tried. Id. 
first women jurors. ${ }^{104}$ Amidst nationwide publicity, excitement, and curiosity, the first women jurors were summoned. ${ }^{105}$ Trying to appease the skeptics, Chief Justice John H. Howe announced to the first women jurors: " [YY]ou shall not be driven by the sneers, jeers and insults of a laughing crowd from the temple of justice .... The strong hand of the law shall protect you." "106 However, most of the women summoned for grand jury service did not take the summons seriously, as there "seemed to have been a mutual understanding that each one, when the term came, would beg to be excused."107

This first "mixed" grand jury, which included six women and had a woman bailiff especially for them, indicted several defendants, one of whom was later tried for a barroom murder by the first mixed petit jury. ${ }^{108}$ During the deliberations, the attorneys, court officials, and general public speculated on the nature of "women jurors." Some argued that women tended to be more perceptive than men, and speculated that the women on the jury would not allow any excuses or extenuating circumstances to spare the defendant from the consequences of his act. Others felt that because women were unlikely to encounter dangerous situations requiring self-defense in their own lives, they would render an unduly harsh verdict. ${ }^{109}$ Finally, some believed that women were "chicken-hearted and could be easily won over" by the oratory of defense counsel, who could effortlessly arouse a woman's sympathy for a man who was on trial for his life. ${ }^{110}$ After two days and two nights of sifting through the facts, the jury proved this last worry to be groundless, finding the defendant guilty of

104. Grace Raymond Hebard, The First Woman Jury, 7 J. AM. Hrst. 1293, 1302-03 (1913). Women's jury service in Wyoming followed the introduction of a bill into the state legislature on November 9,1869 , which provided that every woman at least 18 years old could vote, and guaranteed that their rights to the elective franchise were the same as those of electors. Id. at 1295.

Although many people lobbied to defeat the bill (including those who suggested facetiously that "all colored women and squaws" be substituted for "woman" or that the age requirement be changed to 31 because no woman would ever admit to having that many birthdays and thus no woman would vote), id. at 1296, the Female Suffrage Act passed easily. Coincidentally, Wyoming fell into a state of almost pure lawlessness shortly thereafter; frequent and violent crime, unchecked by an ineffective government, characterized the territory. According to Hebard, "[t]he usual juries could not, or would not, convict those who were captured red handed in their crimes." Id. at 1302. The concept of women jurors suddenly became a primary topic of political discussion, because women, "[t]he better element of the community ... [were] determined to put down the anarchy that ran riot" in Wyoming. Id.

105. Id. at 1302-03.

106. Id. Not surprisingly, parodies and cartoons mocking women jurors soon displaced Chief Justice Howe's noble words. One of the most popular images portrayed women jurors holding their babies in their laps with the caption: "Baby, baby, don't get in a fury; Your mamma's gone to sit on the jury." Id. at 1313.

107. Id. at 1303.

108. Id. at 1313-15. For a competing claimant to the first jury to include women, see The First Jury of Women in the United States, 16 VA. L. REG. (o.s.) 708 (1911) (reporting on the first regular venire of women and the first petit jury made up of only women). Writing for a Virginia periodical, the reporter noted that the first women jurors, whom he called "jury-wo-men," "kept on hats during the whole trial and deliberated for over an hour." He quoted the judge as declaring "that it was the best jury ever sworn in his court." The account concludes with the writer's admission that he could not "help wishing that their services as such will for many years be confined to regions beyond the Rockies." Id.

109. Hebard, supra note 104, at 1316.

110. Id. 
manslaughter. ${ }^{111}$ Despite public skepticism, the verdict met with general approval and many people believed it "could not have been obtained with the usual kind of jury when one considered the times and the sentiment against conviction for murder."112

For the remainder of the Wyoming court's 1870 term, "mixed juries" tried both civil and criminal cases. The community largely ratified their service, and found them unexpectedly harsh enforcers of the law. At the end of the term, the "unanimous verdict of the people was that law had been enforced, crime punished, property protected and 'equal, impartial, exact justice meted out to all in every instance." "113

Women's service on juries in Wyoming was merely a "privilege," however, and privileges can be revoked. With the appointment of a new chief justice, who opposed allowing women to vote or to serve on juries, Wyoming once again barred women from jury service. ${ }^{114}$ In 1892, this prohibition survived its sole challenge, when an alleged cattle thief appealed his conviction on the ground that excluding women from his jury violated the privileges and immunities clause of the Fourteenth Amendment. ${ }^{115}$ The Wyoming Supreme court rejected his claim because he lacked standing, holding that

if women have the right, if it is a right, to serve as jurors, and to 'assist in the administration of justice' thereby, it seems that no one but a woman-one of the class or sex whose rights have been invaded - can assert that right. ... A woman must be on trial to demand the rights of her sex. . . A man ... cannot claim that any civil, political, or other right or privilege of his sex is infringed, invaded, or annulled by ... excluding members of the other sex from the jury $\ldots . .116$

The court left open the question of whether the 1889 Wyoming Constitution, which provided that "[b]oth male and female citizens . . . shall equally enjoy all civil, political, and religious rights and privileges," gave women the right to serve on juries. ${ }^{117}$ Other states also excluded women from jury service throughout the nineteenth century, until Utah became the first state to enact a statute permitting women to serve on juries in $1898 . .^{118}$

111. Id. The bailiff claimed that "the jury agreed more promptly than it might otherwise have done because Saturday night had arrived and the minister's wife [one of the jurors] had Sabbath duties quite equal to those of a jury." Id. The lone juror who supported a verdict of first-degree murder rather than manslaughter reportedly spent the deliberations knitting next to the heating stove, repeating over and over, "Whoso sheddeth man's blood by man shall his blood be shed." Id. at 1315-16.

112. Id. at 1316.

113. Id. at 1325; see also 3 History OF WOMAN SUFFrage 1876-1885, at 731-38 (Elizabeth Cady Stanton, Susan B. Anthony \& Matilda Joslyn Gage eds., 1886) (summarizing the Wyoming trial and the media responses).

114. WYo. STAт. § 3376 (1887) (providing that "all male citizens" meeting certain qualifications "shall be competent persons to serve on all grand and petit juries").

115. McKinney v. State, 3 Wyo. 719, 30 P. 293, 295 (1892).

116. Id. at $726-27$.

117. Id. at 723. The Wyoming court never answered this question; women's jury service was eventually provided for by statute.

118. Rev. Stat. UtaH $\S \S 1297,1299$ (1898) (making women eligible to serve but automatically exempt). In 1911, Washington became the second state to allow women to serve on juries, 1911 Wash. Laws 57, \& 1, and Kansas soon followed, 1913 Kan. Sess. Laws 215 (codified at Kan. Rev. Stat. 
Wyoming's experience with women jurors foreshadowed many of the issues and arguments that appeared frequently throughout the next century. Significantly, the decision to seat women jurors and the reactions to their service both stemmed from the same notions of gender difference. Women were included because it was thought that they would judge facts and issues differently than men, a necessity given Wyoming's conditions of lawlessness and frontier violence. Those who fought to prevent their service also believed that women were different, but different in a manner unsuitable for jurors. Regardless, once the external need for their special contribution diminished, they were no longer permitted to serve. Furthermore, many people expressed concern over the prospect of women jurors neglecting their husbands, children, and socially-imposed duties in favor of jury service. Additional arguments based on the deprivation of citizenship rights were made but rejected. ${ }^{119}$ Yet once women actually served, their performance met with resounding approval.

\section{Stage two: post-Nineteenth Amendment exclusion.}

In the years surrounding the adoption of the Nineteenth Amendment, legal and political commentators vigorously debated the rights and duties incidental to voting. ${ }^{120}$ The result suggested by Neal $v$. Delaware, ${ }^{121}$ which held that voting privileges for blacks encompassed the ability to sit on a jury, was not reached. Many states added women to jury pools as a matter of course. However, the courts of several states held that neither the Nineteenth Amendment, nor parallel state constitutional provisions guaranteeing women's suffrage, entitled women to serve on juries. ${ }^{122}$ These holdings generally relied on a critical

$\S 4611$ (1913)). As in Utah, both Washington and Kansas permitted women to claim automatic exemptions from jury service solely on the basis of gender.

119. McKinney, 3 Wyo. at 725.

120. Julia Margaret Hicks, Women Jurors: Interpreting Constitutions and Statutes (Committee on the Legal Status of Women, National League of Women Voters, 1928) (commenting on court decisions interpreting female suffrage provisions not to include the right of jury service); Minor Bronaugh, Jury Service as Incidental to Grant of Women's Suffrage, 27 Law Notes 147, 150 (1923) (concluding that the adoption of a constitutional amendment for women's suffrage does not mandate jury service); The Effect of Woman Suffrage on Our Present Laws, 6 VA. L. ReG. (n.s.) 454, 454 (1920) (arguing that women "are not bound in law or equity to serve as jurors"); Tried and Approved-The Woman Juror, 70 LrTERARY DIG. 46, 46 (1921) (noting women's automatic eligibility for jury service in Ohio when they won the vote); Women Jurors, 26 CASE \& Comm. 136 (1921) (summarizing cases finding jury service not to be a right incident to suffrage); Note, Constitutionality Under the Fourteenth Amendment and the Proposed Nineteenth Amendment of State Laws Limiting Jury Service to Male Citizens, 6 Va. L. Rev. 589, 592 (1920) (arguing that suffrage is not coextensive with citizenship because jury service is a duty, not a right). Note also the fear that "consideration of sex differences in government affairs cannot be entirely obliterated by the Nineteenth amendment to the constitution is made apparent by the discussion as to the part that women are to play in jury service." Women as Jurors, Cleburne Enquirer, Sept. 2, 1920, microformed on The Grace H. Harte Papers, 1890-1945, ser. III, in Women's Suffrage: The Midwest and Far West (Radcliffe College Women's Studies Manuscript Collections, Congressional Info. Serv.) [hereinafter GRACE H. HARTE PAPERs].

121. 103 U.S. 370 (1881).

122. See People v. Krause, $1906 \mathrm{Ill}$. App. 140, 145 (1915) (holding that women's enfranchisement did not make them eligible for jury service in criminal cases); Commonwealth v. Welosky, 177 N.E. 656, 661 (Mass. 1931), (holding that extension of the vote to women did not expand the scope of the state's jury eligibility statute), cert. denied, 284 U.S. 684 (1932); In re Grilli, 179 N.Y.S. 795, 796 (1920) (rejecting the claim that jury service was incidental to and a part of suffrage). State courts made this constitutional holding even where the legislatures enacted statutes enabling women to sit on juries. 
distinction: courts treated voting as an explicit right of citizenship, but they considered jury service either a privilege or a duty. Thus, courts divorced the right of women to serve on juries from the newly adopted guarantees of suffrage. ${ }^{123}$ This outcome frustrated women's rights advocates, who had "sought jury service as one facet of a greater struggle for recognition in the public life of the community." 124

Women's rights advocates could point to a few isolated successes in the state courts. In one such case, Parus v. District Court, ${ }^{125}$ the Nevada Supreme Court reasoned that the Nineteenth Amendment, like the Fifteenth Amendment, had qualified a new group of citizens as electors, and therefore as jurors. The court concluded:

It may be urged that at the time of the framing of our organic law, qualified electorship was not considered as being attributable to women. But time has wrought the unanticipated change, and by amendment to our Constitution women have been clothed with the qualification of electorship, and by this change the female citizens of the state have automatically become members of the class from which class alone grand jurors may be drawn, and which classification ... constitutes the only circumscription ... fixing the citizenry from which grand jurors might be in the first instance selected. ${ }^{126}$

In an earlier case, Rosencrantz $v$. Territory of Washington, ${ }^{127}$ a Washington state court had also recognized the links between citizenship and jury service. However, the court overruled Rosencrantz a few years later in Harland v. Territory of Washington; ${ }^{128}$ in Washington, as elsewhere, the all-male jury tradition continued. In 1931, eleven years after the Nineteenth Amendment granted women the right to vote, twenty-six states still categorically excluded women

See In re Opinion of the Justices, 130 N.E. 685, 686 (Mass. 1921) (interpreting a state statute to hold that women were not entitled to serve as jurors in light of "the history of the times and the entire system of which the statute in question forms a part"). But see People v. Barltz, 180 N.W. 423, 425 (Mich. 1920) (holding that under a state constitutional provision entitling all citizens to vote, a statute requiring jurors to be drawn from the electors necessarily included women); Commonwealth v. Maxwell, $114 \mathrm{~A}$. 825, 829 ( $\mathrm{Pa}$. 1921) (holding that the Nineteenth Amendment made women eligible to serve as jurors).

123. For insightful discussions of these cases, see Barbara Allen BabCOCK, ANN E. FreedMAN, Eleanor Holmes Norton \& Susan C. Ross, Sex Discrmination and the law: Causes and RemeDIES 64-68 (1975); Jennifer K. Brown, Note, The Nineteenth Amendment and Women's Equality, 102 YALE L.J. 2175, 2185-2201 (1993) (describing the different treatment of voting rights and jury service as "incremental" versus "emancipatory").

124. Barbara Allen Babcock, A Place in the Palladium: Women's Rights and Jury Service, $61 \mathrm{U}$. CIN. L. REv. 1139, 1172 (1993). For comprehensive treatments of the early women's movement, see Florence Ellinwood Allen, To Do Justly 29-38 (1965); William Henry Chafe, The American Woman: Her Changing Social, Economic, and Political Roles, 1920-1970, at 25-47 (1972); Ellen Carol DuBois, Feminism and Suffrage: The Emergency of An Independent Women's MoveMent in America 1848-1869 (1978); FlexNer, supra note 39; William L. O'Neill, Everyone Was Brave: A History of Feminism in America (3d prtg. 1971); Deborah L. Rhode, Justice and Gen-

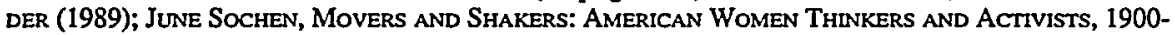
1970 (1973); Up From the Pedestal: Selected Writings in the History of American Feminism (Aileen S. Kraditor ed., 1968).

125. 174 P. 706 (Nev. 1918).

126. Id. at 708-09.

127. 5 P. 305,307 (Wash. Terr. 1884).

128. 13 P. 453 (Wash. Terr. 1887). 
from juries; 129 by 1938 , women remained ineligible for jury service in twentythree states. ${ }^{130}$ Not until 1968 could women serve as jurors in all fifty states. ${ }^{131}$

\section{Stage three: exclusion by exemption.}

Even after states allowed women to serve on juries, they often did not allow them to serve "under the same terms and conditions as men, with the same qualifications, disqualifications, and exemptions."132 For example, throughout the 1960 s, some states automatically exempted women from jury duty unless they affirmatively registered for service. ${ }^{133}$ Other states automatically exempted women at their request. As recently as 1980, twenty-one states, the District of Columbia, and Puerto Rico granted women exemptions based on child-care or family responsibility grounds unavailable to men. ${ }^{134}$

Like most state courts, the Supreme Court refused to base women's jury service on the Constitution, and upheld automatic exemptions for most of this century. In 1946, the Court held in Ballard v. United States that women could not be intentionally and systematically excluded from federal jury service in states that allowed women to serve as jurors. ${ }^{135}$ But the Ballard Court based its decision on its supervisory power, not on constitutional dictates. Women did not become universally eligible for federal jury service until passage of the Civil Rights Act of 1957, which severed federal qualifications for jury service from state qualifications. ${ }^{136}$ Finally, in 1968, Congress passed the Federal Jury Selection and Service Act of 1968, which established a random system to ensure that jury pools included people of every race, color, creed, sex, national origin, and economic status. ${ }^{137}$ This legislation, driven by concerns of representativeness, codified the requirement of a fair cross-section of the community with the understanding that women composed a part of this community. ${ }^{138}$

When the Supreme Court acknowledged that the Constitution applied to the service of women jurors, the Court's concern lay obviously with representativeness, not rights, as it announced that the Sixth Amendment prohibited the systematic exclusion of women from jury venires through the use of statutory registration requirements. ${ }^{139}$ Although the statute in question in Taylor did not facially disqualify women from jury service, "in operation its conceded system-

129. Verna Hildebrand, A Historical Note on Jury Service for Women, Humanist, July-Aug. 1980 , at 38 .

130. Id.

131. Id.

132. Id. at 38-39.

133. See, e.g., WASH. REv. CODE $\$ 2.36 .080$ (1961).

134. Hildebrand, supra note 129 , at 39.

135. 329 U.S. 187 (1946).

136. Pub. L. No. 85-315, 71 Stat. 634, 638 (1957) (codified as amended at 28 U.S.C. §§ 18611878 (1988 \& Supp. IV 1993).

137. 28 U.S.C. §§ 1862-1863 (1988 \& Supp. IV 1993).

138. Id.

139. 419 U.S. 522 (1975) (invalidating a Louisiana statute that required women to declare in writing their desire to be eligible for jury service). Duncan v. Louisiana, 391 U.S. 145 (1968), had applied the Sixth Amendment impartial jury requirement to the states. 
atic impact [was] that only a very few women, grossly disproportionate to the number of eligible women in the community, [were] called for jury service."140 Emphasizing that the selection of a petit jury from a representative cross-section of the community constitutes an important component of the Sixth Amendment right to jury trial, the Court was not persuaded that "all-male venires ... are fairly representative of the local population otherwise eligible for jury service." 141

However, the Taylor Court did not completely eliminate states' power to regulate the composition of jury venires. States remained free to dictate eligibility qualifications as long as the jury lists or panels were representative of the community. ${ }^{142}$ Four years later, in Duren v. Missouri, ${ }^{143}$ the Court invalidated Missouri's jury selection system, which provided automatic exemptions for all women who requested them and resulted in many all-male venires.

During each stage of women's struggle to serve on juries, courts consistently have framed jury selection questions in terms of representativeness rather than citizenship. As the next Part suggests, women's rights advocates, who wanted jury rights at any cost, tried to convince courts that juries without women could neither represent the community nor fulfill the citizenship element of jury service.

\section{B. The Fight for Jury Service}

In the face of a legislator's backhanded reassurance that women "may feel relieved to know that they do not have to begin studying up excuses by which they can escape sitting in jury boxes," 144 women continued a vigorous fight for the right to serve as jurors on the same terms as men. Women's rights advocates engaged in a nationwide struggle to change jury service laws; they provided instruction, information, and political advice to many women, and submitted lists of uniform requests and proposed jury bills to state legislatures. ${ }^{145}$ This campaign constituted part of a larger effort to promote women's equality in all areas, including property, inheritance, guardianship, wage compensation, entry to professions, and election to public office. ${ }^{146}$

Prominent women's rights advocates spent large portions of their time and effort fighting for the right of women to serve on juries. ${ }^{147}$ The National

140. Taylor, 419 U.S. at 525.

141. Id. at 537 .

142. Id. at 538 .

143. 439 U.S. 357 (1979).

144. Women Exempt as Members of Jury: Granting of Suffrage Does Not Change ConSTITUTIONAL DeMAND FOR "MEN" (1921), microformed on GRACE H. HARTE PAPERS, supra note 120.

145. See Genevieve Corkell, The Feminist Demand for Absolute Civic Equality, FED'N NEws, Aug. 30, 1930, at 84 (presenting arguments made for and against a jury bill and quoting prominent male politicians supporting the bill), microformed on GRACE H. HARTE PAPERS, supra note 120.

146. See Some Laws of an Ideal State Which Protect Women and Chlldren (n.d.), microformed on Catharine Gouger (Waugh) McCulloch Papers, 1862-1945, ser. VI, in Women's Suffrage: The Midwest and Far West, supra note 120 [hereinafter Catharine McCulloch Papers]; see also Babcock, supra note 124, at 1172.

147. For evidence of the importance of jury service to the women's agenda in the early 20th century, see Robert Lester, PAPERS OF THE LEAGUE OF WOMEN Voters, 1918-1974, microformed on 
League of Women Voters, for example, provided practical suggestions for local actors to wage the fight for women's jury service. Whether the state's barrier to jury service was the state constitution, a statute, or an opinion of the state attorney general, the League explained how to campaign for a state constitutional amendment, argue for an amendment to the statute, or litigate a test case to supersede the opinion of the attorney general. ${ }^{148}$ Women's groups also disseminated voluminous information on the status of jury rights in each state, tracked progress and setbacks, and encouraged women to fight for their rights on the local level. 149

In 1876, many of the leading suffragists and women's rights advocates in the United States signed their names to a "Declaration of Rights," which demanded among other things that the "civil and political rights that belong to citizens of the United States, be guaranteed to us and our daughters forever."150 The signatories requested the right to vote, the elimination of special legislation for women, and the right to serve on juries. A section of the Declaration called "the Articles of Impeachment" decried the fact that the Constitution guaranteed the right to trial by a jury of one's peers,

yet the women of this nation have never been allowed a jury of their peersbeing tried in all cases by men, native and foreign, educated and ignorant, virtuous and vicious. Young girls have been arraigned in our courts for the crime of infanticide: tried, convicted, hung-victims, perchance, of judge, jurors, advocates-while no woman's voice could be heard in their defence. ${ }^{151}$

The Declaration thus captured the essence of the most troubling aspects of women's exclusion from juries: the treatment of women as second class citizens and the denial to the woman defendant of the benefit of a jury of her peers. As the campaign for women's jury rights continued through several decades, these themes remained central. ${ }^{152}$

GRACE H. HARTE PAPERS, supra note 120 (sketching the biographies of important women in the struggle for jury service).

148. Committee on Uniform Laws Concerning Women, National league of Women Voters, JURY Women (n.d.), microformed on Grace H. Harte Papers, supra note 120 (hereinafter JuRY WOMEN].

149. For a catalogue of the status of women's jury service in each state in the late 1930 s, see National League of Women Voters, Women on Juries 1-2 (1939), microformed on Grace H. HARTE PAPERS, supra note 120; see also JURY WOMEN, supra note 148 (noting that one committee leader advised that "immediate steps should be taken to introduce and press to passage a statutory amendment striking out the word 'male,' where it qualifies 'juror" in the relevant statute).

150. National Woman Suffrage Association, Declaration of Rights of the Women of the United States 4 (1876), microformed on Catharine McCulloch Papers, supra note 146. The Declaration was signed by many important figures of the women's rights movement, including Lucretia Mott, Elizabeth Cady Stanton, Susan B. Anthony, Matilda Joslyn Gage, Laura De Force Gordon, Belva A. Lockwood, and Lillie Devereux Blake. Id. at 4.

151. Id. at 2. juries:

152. The National League of Women Voters catalogued the reasons why women should serve on

1. Responsibility of citizenship. Jury service is a form of participation in the process of government, a social responsibility that should be shared by all citizens-men and women alike.

2. Better balanced verdicts. The complementary viewpoints of women and men tend to result in better balanced jury verdicts.

3. Increase available number of qualified jurors. The number of persons available would be doubled and many women would not need to be excused because of business responsibilities. 
Through the efforts of many advocates, most notably Catharine McCulloch and the Women's Bar Association, women's eligibility for jury service was secured in Illinois in 1939. Grace Harte, who summarized McCulloch's life, illustrated how close jury service was held to the hearts of these women by writing that "[a]s a crowning gratification in her life this remarkable woman, whose activities had spanned more than half a century in every forward movement in her state, was called upon to serve as foreman of the federal grand jury in [Illinois federal court]." 153

\section{Citizenship.}

The connection between jury service and citizenship has long been emphasized by women's rights advocates. An important element of equality, commentators argue, is the right "to share the basic obligations of public citizenship."154 Women's jury advocates have always maintained that the right to serve on juries, like the right to vote, is a symbol of equal citizenship. Equality "does more than bestow entitlements on individuals, for the notion of citizenship, to which liberty is related both constitutionally and normatively, also incorporates the responsibilities that accompany membership in the society."155 To the extent that laws permitted or mandated the exclusion of women from jury service, they exempted women from one of the crucial obligations of citizenship. This exemption rendered women "less than full citizens, cared-for rather than responsible."156

Although arguments drawing the connection between women's jury service and citizenship appear in modern literature and legal briefs, they first emerged long before this era. Similar citizenship-based arguments were used in $E x$ parte Mana, a 1918 case challenging the constitutionality of a California statute making women eligible for jury service. The defendant appealed his rape conviction because it had been returned by a jury of seven women and five men. $\mathrm{He}$ argued that the presence of women on his jury violated a provision of the California Constitution, which stated that "[t]he right of trial by jury shall be

\footnotetext{
4. Why not? Women are in the courts in the capacity of plaintiffs, defendants, judges, lawyers, clerks, and stenographers. Why should the jury box be closed to them? WOMEN ON JURIES, supra note 149 , at 3.

153. Biographical Sketch of Catharine Waugh McCulloch (1942), microformed on Grace H. Harte PApERs, supra note 120, at 1. As early as 1926, the Women's Bar Association had described efforts to secure the passage of a bill allowing women to serve on juries in Illinois as their "principal endeavor for the year." WOMEN's BAR Assoctation of Ilinois: 20Th ANNIVERSARY JourNal aND Directory 1934-35, at 26 (1935), microformed on GRACE H. HARTE PAPERS, supra note 120. In 1934, the Association voted to "concentrate the energies of the Association for the enactment of a [jury bill]," id. at 27, and its 1941-42 membership directory listed a special committee for jury service of significant size. WOMEn's Bar Association of IlinoIs: 1941-42 Membership Directory (1942), microformed on GRACE H. HARTE PAPERS, supra note 120.

154. David L. KirP, Mark G. Yudof \& Marlene Strong Franks, Gender Justice 88 (1986) (justifying their claim for equal liberty by arguing that if "the governing norms deny the claim of autonomy and shelter individuals from the responsibilities of state, then people become dependents. . [,] remain[ing] childlike, unable fully to act for themselves in exercising rights and fulfilling responsibilities.").
}

155. Id. at 103 .

156. Id. 
secured to all, and remain inviolate."157 The primary issue in Mana was whether the inclusion of women on the jury had destroyed this seemingly essential characteristic-maleness-of the common law jury. An amicus brief filed in defense of the statute's constitutionality by Gail Laughlin, the author of California's jury service bill, ${ }^{158}$ claimed that exclusion from jury service constituted tacit approval of women's "inferiority in civil society, lessening the security of their enjoyment of the rights which others enjoy ... ." "159 Meanwhile, Mana's counsel cautioned, "'Let the jury system alone' should ever be the slogan of every liberty loving individual."160

In more modern cases, advocates continued to rely on this connection between jury service and citizenship to push for the removal of barriers to women's jury rights. In Hoyt v. Florida, the ACLU argued with respect to jury service that it is "the right and corollary obligation of fully enfranchised women, citizens in the exact sense of the word, to participate in this important public duty ...."161 Drawing out a startling disparity in treatment, the ACLU noted that when

slaves won their freedom in the United States they automatically gained all the rights that went with citizenship, whereas, when women won the vote after fifty years of struggle, the vote was all they got.... The defect of sex still hung heavy upon them and they had to fight separately for all the other rights that go with citizenship. ${ }^{162}$

The harm of exclusion was unquestionably recognized by the women excluded and those observing. As then-advocate Ruth Bader Ginsburg argued in Stubblefield v. Tennessee, "automatic exemption on the basis of sex is at best misguided chivalry. In failing to recognize adult females as persons with full civic

157. Points and Authorities in Opposition to Petition at 1, Ex parte Mana, 178 Cal. 213 (1918) (Crim. No. 2145) (quoting CAL. Const. art I, § 7)). The petitioner's argument that the inclusion of women jurors violated his jury rights rested on a variety of sources, including Webster's dictionary definition of a jury as "a body of men," historical descriptions of the common law jury, and the Magna Carta, which did not allow women to serve. Petitioner's Points and Authorities at 3-6, Ex parte Mana (Crim. No. 2145). Moreover, he argued,

[f]rom time immemorial it has ever been regarded that a jury is a BODY OF MEN. In its very nature, it must consist of men ... and it is in that sense, and only in that sense that English speaking people have used it from the earliest times. .. . Were the phrase "of men" added, or had it been added [to the constitutional jury provision], it would amount to pure surplusage, because the word, itself, carries the phrase with it. Id. at 4.

158. Petition for Permission to File Brief, Ex parte Mana (Crim. No. 2145). As the author of the then pending jury bill, Gail Laughlin filed her brief to represent "the interest of 75,000 women who, through their organizations, requested of the Legislature the enactment of said law." Id. at 1.

159. Points and Authorities in Behalf of Various Organizations of Women at 23, Ex parte Mana (Crim. No. 2145) (quoting Strauder v. West Virginia, 100 U.S. 303, 308 (1879)).

160. Petitioner's Points and Authorities at 6, Ex parte Mana, (Crim. No. 2145). The Califormia Supreme Court ultimately upheld the jury service statute as a legitimate exercise of legislative power, since the state constitution recognized women "as in all respects the equal of" men. Ex parte Mana, 178 Cal. 213, 216, 172 P. 986, 987 (1918).

161. Brief of the Florida Civil Liberties Union and the American Civil Liberties Union, Amici Curiae at 3, Hoyt v. Florida, 368 U.S. 57 (1961) (No. 31) [hereinafter ACLU Amicus BRIEF].

162. Id. at 13 (citation omitted). 
responsibilities as well as rights, Tennessee's jury service laws betray a view of women ultimately harmful to them."163

The citizenship argument has recently appeared in tandem with representativeness claims. In Duren v. Missouri, for example, the petitioner challenged an opt-out system for all women. Although the main arguments in the case focused on the system's violation of the Sixth Amendment's fair cross-section requirement, petitioner's counsel also noted that "[j]ury service is 'acclaimed as one of the basic rights and obligations of citizenship,' 'a form of participation in the process of government." "164 Moreover, counsel argued that "[a] scheme that treats men's service as essential, women's as expendable, hardly assists female citizens to view themselves and be viewed by others as fullfledged participants in community affairs." 165 In another Sixth Amendment case, Edwards v. Healy, the defendant's counsel used similar arguments to explain that

[b]y keeping women off the jury rolls unless they volunteer, Louisiana hardly assists its female citizens to view themselves and be viewed by others as fullfledged participants in community affairs. Rather, the state types women as persons whose assistance in the administration of justice is not really needed by the community. 166

Thus, a brief look at the history of advocacy for women's jury service demonstrates that women viewed the loss of citizenship rights as one of the most harmful implications of being deprived of jury service.

\section{Jury of her peers.}

The injury inflicted by excluding women jurors was often depicted in legal briefs, political material, and other commentary in terms of a female defendant, or a male defendant accused of a crime against a woman, tried by an all male jury. In both of these situations, it was argued, women were needed on the jury. Catharine McCulloch, a major figure in this struggle, wrote an early twentieth century play using this model, "depicting the prejudice against [a law qualifying women as jurors] on the part of a male head of a family, and his conversion to the idea of women on juries where certain female members of his family were involved in a court trial."167 In 1961, the ACLU presented similar arguments before the Supreme Court in Hoyt v. Florida, stating that one of the most serious rights affected by jury service is

the right of the woman accused of crime to have her case heard by a jury composed of the broadest possible cross-section of the people making up her community, her neighbors and her peers, so that its impartiality may be insured

163. Jurisdictional Statement at 10, Stubblefield v. Tennessee, 420 U.S. 903 (1975) (No. 736598). In the past decade, the jury commissioner in the county in which this case arose had called 2238 men for jury duty, but only 21 women, none of whom actually served. Id. at 6 .

164. Brief for Petitioner at 21, Duren v. Missouri, 439 U.S. 357 (1978) (No. 77-6067) (quoting

Penn v. Eubanks, 360 F. Supp. 699, 702 (M.D. Ala. 1973)).

165. Id. at 22.

166. Brief for Appellees at 21, Edwards v. Healy, 421 U.S. 772 (1975) (No. 73-759).

167. Biographical Sketch of Catharine Waugh McCulloch, supra note 153, at 1. 
by the wideness and diffusion of the interests it represents. In such a crosssection can anyone doubt that women play an enormously important part! 168

These images play on the assumption that women jurors bring certain experiences to bear on the factfinding process-experiences that are deemed especially important in cases involving female defendants or victims. As Catharine McCulloch explained:

The need of accused women for women jurors, the needs of wronged women to have some women jurors hear their cases is great. A shabby, poverty stricken, adolescent girl victim is not as interesting to some male jurors as is a clever, well-dressed, handsome adventuress who has killed her last husband. Women jurors, however inexperienced, would not be liable to be completely hoodwinked. 169

In an address to the Michigan Constitutional Convention, she asserted that:

It is not possible that impartial juries should be the rule when women stand before them accused of crime or when wronged women have asked justice against men assailants. ... . Men jurors generally fix inadequate penalties for wrongs done women and girls. They can never be expected to go ahead of the law, and law shows little delicate discrimination between wrongs against women and animals. ${ }^{170}$

The concern underlying her comment is that "when either a wronged woman or an accused woman stands before a jury of men it is not an impartial jury. It is a jury of her political superiors."171

However, women's advocates attempting to convince lawmakers and judges that the presence of women on juries would enhance the fairness of the trials of women defendants had to carefully balance their arguments with their efforts to calm the widespread fear that women jurors would always act alike. In describing the failure of an Illinois jury bill in 1925, Grace Harte explained to Catharine McCulloch that there was

quite a bit of talk among certain of the representatives that if women are on juries they will send every bootlegger to jail; and I have even argued that women are both wet and dry and they must not assume what women will do in those cases; but then I am met with the answer that, whether wet or dry, they are more likely to "enforce the law." That's our reputation!172

Within the women's movement, then, the fight for jury service was broadly conceived as implicating many different rights and issues. As the next Part demonstrates, however, courts and legal commentators greatly narrowed the range of issues by ignoring citizenship-based arguments and focusing solely on gender difference. As a political strategy, women had to reframe their legal

168. ACLU AMicus BRIEF, supra note 161 , at 26-27.

169. JURY WOMEN, supra note 148, at 4.

170. Catharine Waugh McCulloch, Address before the Michigan Constitutional Convention (Jan. 8,1908 ), at 14, microformed on Catharine McCulloch Papers, supra note 146.

171. Catharine Waugh McCulloch, Illinois Laws Concerning Women 26, microformed on Catharine McCulloch Papers, supra note 146.

172. Letter from Grace H. Harte to Catharine Waugh McCulloch (June 25, 1925), microformed on Grace H. Harte Papers, supra note 120. 
arguments in terms commensurate with the courts' goals-difference rather than rights. Even today, feminist scholars often argue that men and women view the world from different perspectives and speak in different voices. This preoccupation with gender difference unwittingly perpetuated the use of sexbased peremptory challenges.

\section{The Role of Gender Difference in the Debate About Women's Jury Service}

Susan Glaspell's one-act play, Trifles, sheds considerable light on the role of gender difference in the debate about women's jury service. The 1917 play is set in the abandoned farmhouse of John Wright, who had been strangled recently in his sleep. ${ }^{173}$ His wife, Minnie, was taken into custody on suspicion of murder. As the play begins, all of the characters gather in the disorderly kitchen of the farmhouse. Three men-the sheriff, the county attorney, and a neighbor-and two female neighbors examine the kitchen for clues to the murderer's identity and motive. The men conclude that there is "nothing important here-nothing that would point to any motive. . . . Nothing . . . but kitchen things." 174

The men move upstairs, and then to the barn, to continue their search for evidence. Meanwhile, the two women remain in the kitchen, preoccupied with Minnie's half-finished preserves and chores. As the men leave the kitchen, they scoff at the women's dalliance, noting that "women are used to worrying over trifles." 175 But, once alone, the women discover a strangled bird wrapped neatly in a piece of fine silk. ${ }^{176}$ One of the women, lost in her own thoughts, comments that "[i]f there'd been years and years of nothing, then a bird to sing to you, it would be awful-still, after the bird was still."177 The women understand who murdered Mr. Wright. They find the motive for Mrs. Wright's murder of her husband in the dead bird and her broken stove-evidence of Mr. Wright's cruelty and Mrs. Wright's life without joy. ${ }^{178}$

Debating whether the men would consider the dead canary an important clue, the women overhear the county attorney state that although he thought Mrs. Wright had killed her husband, without "something to make a story about-a thing that would connect up [Mrs. Wright] with this strange [murder]," no jury would convict her. ${ }^{179}$ The women conceal the dead bird, destroying the best evidence of the motive for the murder and preventing a jury from even hearing the case.

This play captures the essence of the narrowed legal debate about including women on juries: whether or not there is something distinctly different about

173. Susan Glaspell, Trifles: A Play in One Act, reprinted in Plays by American Women: The EarLy Years 145, 149 (Judith E. Barlow ed., 1981).

174. Id. at 152 .

175. Id. at 153 .

176. Id. at 160 .

177. Id. at 161 .

178. See Massaro, supra note 29, at 552-53 (discussing and interpreting Glaspell's play Trifles).

179. Glaspell, supra note 173 , at 162. 
the perspective of women, and whether that difference adds to, or detracts from the factfinding mission of a jury. ${ }^{180}$ But the play also captures an important strategy of the fight for jury service-an emphasis on difference that results from a recognition of the courts' narrow understanding of the issue. Susan Glaspell was a suffragist trying to advance the legal status of women. ${ }^{181}$ Perhaps recognizing difference as the best argument for women's jury service, she wrote the play to demonstrate that the different insights and understandings women bring to the interpretation of facts may lead to more accurate factfinding. These special insights, she put forth, necessitate the service of women on juries.

The question of whether juror insights are distinctively "gendered" runs through the case law, as well as the sociological, psychological, and historical literature. A recent historical exploration of women's exclusion from juries concludes that "both the proponents and opponents of women's jury service shared assumptions . . . about the existence and nature of fundamental differences between women and men. The two sides diverged, however, in the implications they drew from those shared assumptions." 182

The theory of women's unique contribution to deliberation directly countered the popular claim that they were unsuited to serve. No stigma attached to women's exclusion because they were seen to inhabit a higher and finer sphere. But their absence from juries meant that simply proving women were "equally qualified" was insufficient. Before women had gained even minimal equal protection guarantees, this focus on women's unique perspective made sense. Women had to demand their inclusion as a necessity, even though among themselves they actually believed in a broader justification. ${ }^{183}$

With difference as the basis for bringing women onto juries, courts never revisited the citizenship issue. Despite recognition of equality in other areas, arguments for and against women's jury service have continued to focus on gender difference to the present day. Two distinct ideologies of womanhood aided courts in their failure to refocus on citizenship rights: women and their special domestic sphere, and women as especially fit or unfit jurors.

\section{Women and the "special sphere."}

Many early state statutes governing jury service reflected a widely held notion that the state had a duty to keep women in their "special sphere" of the

180. See Robert M. Cover, Owen M. Fiss \& Judith Resnik, Procedure 1167-68 (1988) (noting that the play Trifles illustrates the difference between the learning/judging processes of women and men); Marcia Noe, Susan Glaspell: Voice from the Heartland 33-34 (1983) (painting Trifles as "a play about sisterhood and sexual politics" which emphasizes the "difference between the way men and women experience reality" and illustrates "that the female mode of perception ... serves as a bond to unite women in sisterhood when they are threatened by male oppression"); ARTHUR E. WATERMAN, SUSAN GLASPELl 91 (1966) (concluding that Glaspell's plays generally were designed to reflect themes in the "intellectual, experimental, and traditional elements" of society, including feminism).

181. Cover ET AL., supra note 180, at 1167 (describing Glaspell's friendships with many contemporary leading women's rights advocates who were fighting for suffrage and for the right to serve on juries).

182. Carol Weisbrod, Images of the Woman Juror, 9 HARv. WoMEN's LJ. 59, 61 (1986).

183. See text accompanying notes 144-166 supra. 
home and hearth in part by discouraging their participation on juries. ${ }^{184}$ The prevalence of special-sphere arguments suggests that women's exclusion from juries resulted not from group prejudice, but from what society then considered to be a positive goal-to preserve gender roles. Believing that the exclusion of women was beneficial and not stigmatic, proponents of special-sphere ideology based their theory on several assumptions: women, rather than men, should bear domestic responsibilities; ${ }^{185}$ jury service would compromise women's primary role in society; ${ }^{186}$ and removal from their domestic sphere would cause women to replace "female" values necessary to preserve the home and family with "male" values necessary to understand and participate in politics and business. ${ }^{187}$

Efforts to confine women to their domestic roles extended beyond the issue of jury service, ${ }^{188}$ as this battle was merely one aspect of women's struggle for full citizenship. ${ }^{189}$ This pursuit met with great resistance from those who wished to assign women to "a place before the law different and distinct from that of [men]," and "preserv[e] and promot[e] the dominance of male over female."190 Much to the frustration of women's rights advocates, separate sphere ideology justified excluding women from other important aspects of citizenship: voting, practicing law, owning property, and participating fully in the

184. See Copelon et al., supra note 92 , at 8-9.

185. See id. at 6 (arguing that "sex discrimination in jury selection systems has been justified primarily on the ground that, for women, jury service is an interference with domestic responsibilities, the uninterrupted performance of which is more important to society than her participation on the jury"); Mahoney, supra note 40, at 210 (explaining that legislators and judges believed that "women belonged in the home, that they were too emotional and sensitive to be exposed to the unpleasant events occurring in courtrooms, and that they were intellectually incapable of following complex legal arguments"); Taylor, supra note 29, at 231 (arguing that home and family responsibilities supply the primary arguments against compulsory jury service for women); Weisbrod, supra note 182, at 62 (arguing that a central assumption on both sides of the woman juror debate "was that women's special sphere was the home").

186. Shirley S. Abrahamson, Justice and Juror, 20 GA. L. Rev. 257, 268 (1986) (finding that "one of the major concerns of the opponents of jury service for women was the envisioned neglect of home and children"). Another commentator explained:

The fact is that the jury question will bring out more clearly than the law has ever appreciated

the truth that motherhood is an occupation, one of the most engrossing occupations in the

world. The mother must evidently be classed with those men who, like locomotive engineers,

do work from which they cannot be spared for any long period of time.

Id. at 269 (citing Women on Juries, 7 WOMEN's L.J. 37, 38 (1918)).

187. See, e.g., Claudine Herrmann, The Virile System, in New French Feminisms: An ANTholoGY 87, 89 (Elaine Marks \& Isabelle de Courtivron eds., 1980) ("If [a woman] adopts masculine values ... like coldness and imperialism, she will succeed only by destroying herself .... What she gains in the social arena she will lose on a personal level. It means nothing to allow women to participate in society if it robs them of everything that makes them different.").

188. Nonetheless, jury service was a major focus of the women's movement. See, e.g., FLEXNER, supra note 39, at 164 (finding that jury duty was "one of the most basic demands voiced by women"); Aileen S. Kraditor, The Ideas of the Woman Suffrage Movement: 1890-1920 (2d ed. 1981); RHODE, supra note 124 , at $48-50$.

189. National League of Women Voters, Pamphlet of Committee on Uniform Laws ConCERning Women (n.d.), microformed on Catharine McCulloch Papers, supra note 146; Catharine Waugh McCulloch, Address before the Michigan Constitutional Convention, supra note 170.

190. Wendy W. Williams, The Equality Crisis: Some Reflections On Culture, Courts, and Feminism, 7 WOMEN's RTs. L. REP. 175, 177 (1982). 
labor force. ${ }^{191}$ For example, as Clara Shortridge Foltz, the first woman lawyer on the Pacific Coast, noted, the "issue always became the nature and place of Woman: her sphere."192 Lobbying to enable women to practice law, Foltz, and many others of her time, encountered the persistent and widespread belief that "[v]oting or practicing law would move women into the public sphere, "unsexing' them, and thus making them unfit for domestic life."193

The Supreme Court itself fell prey to separate-sphere arguments. In the now notorious words of Justice Bradley from an 1872 case,

[c]ivil law, as well as nature herself, has always recognized a wide difference in the respective spheres and destines of man and woman.... The constitution of the family organization, which is founded in the divine ordinance, as well as in the nature of things, indicates the domestic sphere as that which properly belongs to the domain and functions of womanhood. [T] he harmony, not to say identity, of interests and views which belong, or should belong, to the family institution is repugnant to the idea of a woman adopting a distinct and independent career from that of her husband. ... The paramount destiny and mission of woman are to fulfil the noble and benign offices of wife and mother. This is the law of the Creator. And the rules of civil society must be adapted to the general constitution of things, and cannot be based upon exceptional cases. ${ }^{194}$

Separate-sphere ideology persisted in the Supreme Court's decisions on women's jury service well into the twentieth century. For example, in a 1961 case, Hoyt v. Florida, ${ }^{195}$ the Court rejected a Fourteenth Amendment challenge brought by a female defendant who had been convicted of second-degree mur-

191. See Muller v. Oregon, 208 U.S. 412, 421-22 (1908) (upholding limitations on the work hours of women in the paid labor force); Bradwell v. Illinois, 83 U.S. (16 Wall.) 130, 141 (1872) (denying women the right to practice law and upholding a maximum hour law for women); In re Lockwood, $9 \mathrm{Ct}$. Cl. 346 (1874), reprinted in 1 CENT. L.J. 254, 256 (1874) (justifying the exclusion of women from its bar because women's "legal position is ... interwoven with the very fabric of society" and "immemorial usages" of women forbid a far-reaching change); In re Goodell, 39 Wis. 232, 245 (1875) (refusing to allow women to practice law on the grounds that the "law of nature destines and qualifies the female sex for the bearing and nurture of the children of our race and for the custody of the homes of the world and their maintenance in love and honor"). The Muller Court explained that "[t]hough limitations upon personal and contractual rights may be removed by legislation, there is that in her disposition and habits of life which will operate against full assertion of those rights. She will still be where some legislation to protect her seems necessary to secure real equality of right." Muller, 208 U.S. at 422 . The Court also denied that the lack of suffrage for women in Oregon was solely the result of political inequality; rather, the "reason runs deeper, and rests in the inherent difference between the two sexes, and the different functions in life which they perform." Id. at 423 .

192. See Barbara A. Babcock, Clara Shortridge Foltz: "First Woman," 30 ARIz. L. Rev 673, 675 (1993). When Foltz applied to study with Francis Spencer, a prestigious lawyer, he wrote a letter to her stating that by practicing law she "would invite nothing but ridicule if not contempt." He explained that "a woman's place is at home, unless it is as a teacher." Id. at 685.

193. Id. at 688. Babcock suggests that the reluctance of states to admit women to their respective legal bars stemmed from the belief that

law had little connection with the domestic sphere, or with the ideal world of nurturance and tender feeling that nineteenth century women were supposed to inhabit. Nothing could be more inconsistent with the social image of the true woman than the type of the good lawyer: bold, brilliant, aggressive, incisive, and ruthless in the interests of justice or of a client.

Id. at 715-16.

194. Bradwell, 83 U.S. (16 Wall.) at 141.

195. 368 U.S. 57 (1961). 
der by an all-male jury. Hoyt allegedly beat her husband to death with a baseball bat after he rejected her attempts at reconciliation. She claimed that the Florida jury selection statute, which exempted women from jury duty unless they affirmatively volunteered to serve, violated the Equal Protection Clause because it effectively excluded all women from jury service. ${ }^{196}$ Hoyt argued that women jurors would likely have been more sympathetic to her temporary insanity plea. ${ }^{197}$

The Supreme Court sustained her conviction, declaring the automatic exemption for women "reasonable" because women belonged in the home, caring for the family. 198 According to the Court, a state could rationally determine that excusing women from jury duty served the general welfare, unless a woman felt a need to serve for some reason. ${ }^{199}$ Moreover, the Court held that statistics demonstrating the actual scarcity of female volunteers on Florida's jury lists failed to prove that the state violated the defendant's rights. ${ }^{200}$ In reaching this decision, the Court ignored arguments presented in the ACLU's amicus brief that the de facto exclusion of women denied them the rights of "fully-fledged emancipated citizens."201

The mid-twentieth century cases on this issue all carry the same messagecourts believed that the exclusion of women from juries benefitted women themselves and society as a whole by encouraging women to fulfill their special domestic role in the world. Although current equal protection doctrine mandates that courts apply heightened scrutiny to legislative classifications based on $\operatorname{sex}^{202}$ and would likely strike down the exemption upheld in Hoyt, the

196. Id.

197. Id. at 59.

198. Id. at 61-63. After Hoyt, state and federal courts similarly upheld automatic exemptions for women from jury service. See, e.g., Leighton v. Goodman, 311 F. Supp. 1181, 1183 (S.D.N.Y. 1970) (finding that because "the great majority [of women] constitute the heart of the home, where they are busily engaged in the 24-hour a day task of producing and rearing children, providing a home for the entire family, and performing the daily household work, all of which demands their full energies," New York could rationally exempt women "in order not to risk disruption of the basic family unit"); State v. Hall, 187 So. 2d 861, 863 (Miss.), cert. dismissed, 385 U.S. 98 (1966) (upholding a jury selection system which granted women exemptions solely because of their sex and remarking that "[t]he legislature has a right to exclude women so they may continue their service as mothers, wives, and homemakers, and also to protect them ... from the filth, obscenity, and noxious atmosphere that so often pervades a courtroom during a jury trial").

199. Hoyt, 368 U.S. at 62.

200. The list from which Gwendolyn Hoyt's trial jury was selected included 10 women and approximately 210 men. Id. at 67.

201. ACLU AMICUS BRIEF, supra note 161, at 24.

202. See Craig v. Boren, 429 U.S. 190 (1976) (holding that the Constitution requires that genderbased classifications serve important governmental objectives and be substantially related to the achievement of those objectives). Using heightened scrutiny, the Court has struck down a number of statutes which treated similarly situated men and women differently. See, e.g., Califano v. Goldfarb, 430 U.S. 199 (1976) (striking down a provision of the Social Security Act that presumed dependency of a wife on her deceased husband for purposes of death benefits but required a husband to prove dependency on his wife to receive the same benefits); Weinberger v. Wiesenfeld, 420 U.S. 636 (1975) (invalidating a statute that denied father's insurance benefits to surviving widowers with children in their care while authorizing similar mother's benefits to similarly situated widows); Frontiero v. Richardson, 411 U.S. 677 (1973) (invalidating a statute that provided increased benefits to martied male members of the Armed services whether or not their wives in fact depended on them, while granting married female service members increased benefits only if they in fact provided over one-half of their husbands' sup- 
assumptions about women's nature that underlay the exemptions persist. ${ }^{203}$ As late as 1970, a court suggested that the challenger's "lament [that women were insufficiently represented on the jury] should be addressed to the Nineteenth Amendment State of Womanhood" which prefers "cleaning and cooking, rearing of children and television soap operas, bridge and canasta, the beauty parlor and shopping, to becoming embroiled in plaintiff's problems with her landlord."204

Because of the persistence and strength of separate-sphere ideology, advocates of women's jury service had to counter and simultaneously rework these arguments to avoid total exclusion. Women's rights advocates argued that juries must include women precisely because men and women operate in different or special spheres of life, conceding only the need for narrowly drawn exemptions for women with small children. To the extent that men and women occupy separate spheres, women "would, as jurors, make a distinct contribution to the elucidation of the problems to be solved in the jury room."20s Many advocates also argued that because women were less familiar with the traditionally male aspects of public life, they had "'fewer business and political prejudices than men, and [were] therefore less likely to let such prejudices become factors in the verdicts they render[ed]." "206 Furthermore, because women operated in a less time-constrained sphere than men, they could provide a more reliable pool of jurors than one comprising only men. ${ }^{207}$

Proponents of women's jury service also argued that it would not even interfere with the special sphere that society preferred to reserve for women. Some argued for voluntary, rather than compulsory, women's jury service, perceiving such service as a right and incident of citizenship, yet respecting the concerns of those who wanted women to remain the center of home and family life. ${ }^{208}$ By exempting women unable to serve due to their domestic duties, laws

port). The statute attacked in Hoyt would almost certainly fail to satisfy heightened scrutiny today, since automatic exemptions clearly depend on "archaic and overbroad" generalizations about the role of women in society, and their restricted ability to participate as full citizens without compromising their domestic responsibilities.

203. See text accompanying notes $233-258$ infra.

204. Dekosenko v. Brandt, 63 Misc. 2d 895, 898, 313 N.Y.S.2d 827, 830 (Sup. Ct. 1970), aff'd, 26 A.D.2d 796, 318 N.Y.S.2d 915 (App. Div. 1971).

205. P.A. Jacobs, Women Jurors, 7 Austh. L.J. 262, 263 (1933); see also Amber Wallin Anderson, Jury Service for Women?, 11 GA. B.J. 196, 198 (1948) (arguing that "[a] woman's viewpoint is needed in the courtroom in all cases-and particularly in cases involving sex offenses"); Miller, supra note 80 , at 48 (advocating women's jury service on the grounds that women have "gone intelligently through an extremely important phase of life which is in a measure closed to men, [and] can as a resuit, render substantial aid in working out [theories of crime] and other problems in the administration of justice").

206. Women as Jurors, 32 LAw Notes 124 (1928) (quoting a judge from Iowa).

207. See Women Jurors, 26 LAw Notes 224 (1923) (quoting Judge Florence Allen as saying, "Educated women have more leisure, unless they have young children, than business men, and therefore we find them less apt to evade jury duty than men of the same class."). But cf. Miller, supra note 80, at 45 (warning "that after the novelty of the thing is over ... the better type of women will lose interest just as many of the better type of men have done, and the ones who accept service will be the scandal-loving, professional juror type").

208. See, e.g., JURY WOMEN, supra note 148, at 3. 
extending jury service to women would not disrupt the traditional social structure.

Of course, not all advocates of women's jury service based their views upon a respectful understanding of women's special sphere. One commentator, though ultimately concluding that women should be called for jury service, wrote,

It is a serious question whether all married women having sole charge of their households should not be exempt. Man has few enough rights left without impairing his age old right to a warm dinner, subject only to the equally ancient qualification of the willingness of his spouse to prepare it.209

A contemporary suggested that even if one assumes that the Fourteenth Amendment permits "the exclusion of certain classes of citizens from jury service ... on the bona fide ground that it is for the good of the community that the regular work of the excluded classes shall not be interrupted," women should still not obtain automatic exemption from jury service. ${ }^{210}$ Not all women, he argued somewhat bitterly, deserved exemptions:

[Often] the women involved have no regular or any other kind of work. Many present day women, who raise no children or have them raised; who live in apartments perhaps, or in their fathers' or husbands' homes cared for by their employees, and whose occupation consists of window-shopping and making calls, when they are not engaged in studying the fashion magazines, certainly do not qualify for exemption. Moreover where the exemption is placed on a basis of personal choice, it is far more probable that the woman who elects to serve is a busy but conscientious woman, or one who is glad of the opportunity to vary the routine drudgery of her work..$^{211}$

Finally, although some advocates of women's jury service conceded that jury service might interfere with women's domestic responsibilities, they argued that the benefits of having women on juries outweighed such interference. One commentator suggested that jury service by women might "result in late dinners and unswept floors," but found these inconveniences minor. ${ }^{212}$ Another argued that it was "far more "for the good of the community' that cooking and dishwashing should suffer temporarily at the hands of the high school girl next door," than that society should continue to administer justice without the input of women. ${ }^{213}$

\section{Women as unfit or especially fit jurors.}

Although much of the debate over women serving on juries has focused on its potential effect on women's role as the center of family life, an important element of the debate addressed the very qualifications of women to serve. Many opponents of women's jury rights simply considered women unfit for

209. Women Jurors, supra note 207, at 224 (arguing against women's jury service because it might compromise the understood importance of women's domestic duties).

210. Miller, supra note 80, at 47 (quoting 16 R.C.L. 229 (1917)).

211. Id.

212. Rudolph, supra note 80 , at 100 .

213. Miller, supra note 80 , at 48 . 
jury duty, claiming they were intellectually weak, unknowledgeable about the workings of society and business, emotionally unprepared, ${ }^{214}$ and too fragile to be exposed to the nastiness of trials. ${ }^{215}$ They argued that the flow of trials would suffer, because "[w]omen are not only embarrassed themselves by service on a jury, but they are sometimes very embarrassing to lawyers on both sides of a case who do not know the psychology of a woman's mind and are not sure which way she is going to jump."216 And, whether or not women were fit to serve on juries, they claimed that courthouses were not fit to serve women, because they lacked facilities for women jurors. ${ }^{217}$

For years, judges, lawyers, and commentators found women too emotional, irrational, and naive to serve on juries. After one lawyer served on a jury himself, he argued that "women as a whole are temperamentally unfit for jury duty." Women jurors, he argued, are guided by a "feminine logic" incapable of providing any more of an explanation for a verdict than "because."218 Special concerns arose regarding women serving as jurors in certain kinds of cases. In Ex parte Mana, for example, counsel for a convicted rapist argued on appeal (perhaps motivated more by self-interest than an objective assessment of women's ability to serve):

Rape is a crime against woman kind-a crime committed against that sex. May it not be possible that women, sitting in such a case, would be bound to return a verdict of guilty on the slightest pretext, as a matter of self preservation, or possibly, to avoid reflections upon her own chastity.... [O]ne thing we do know, and that is certain; A [sic] defendant charged with the crime of rape stands about as much chance for an acquittal at the hands of a woman jury as an icicle stands for survival in the hottest furnace within the domains of his Satanic Majesty. ${ }^{219}$

\section{Another critic of women's jury service elaborated that underlying}

the whole question of women jurors, women voters, women legislators, women generally in public life, looms forth one great and indisputable fact, and that is that woman approaches the problems of life with her heart, and not with her head .... So long as she is a woman, her emotional strain will dominate her

\section{See notes 109-110 supra and accompanying text.}

215. Women as Jurors, 93 CENT. L.J. 57 (1921). The concern that women's finer sensibilities would be affected by jury service was always present. See Petitioner's Points and Authorities at 13, Ex parte Mana, 178 Cal. 213 (1918) (Crim. No. 2145) (urging that California not allow "our mothers, our wives and our daughters [to] rub elbows with any possible libertine and rough-neck that might sit on a jury and enter into heated arguments with him concerning matters of a sexual nature.... The very idea is revolting in the extreme.").

216. Women as Jurors, supra note 215 , at 57.

217. See Miller, supra note 80 , at 42 (noting that the practical difficulty of "keeping the jurors together" during their deliberations has been a much debated topic).

218. H.W. Powell, A Lawyer on the Jury, 24 CASE \& CoM. 740 (1918).

219. Petitioner's Points and Authorities at 14, Ex parte Mana (Crim. No. 2145). Gail Laughlin simply responded in an amicus brief that "unless [defendant's counsel] denies to women the intelligence to discriminate between guilt and innocence, it would be only the guilty who would suffer." Points and Authorities in Behalf of Various Organizations for Women at 22-23, Ex parte Mana, (Crim. No. 2145). 
rational processes, and she will continue to be the inspiration of romance, poetry, and art as long as civilization shall endure. ${ }^{220}$

Others worried that women's assumed lack of knowledge about public life would impede their ability to understand complex issues which might arise during a trial. For example, one woman who served on a petit jury sensed that the lawyers in the case thought that "women knew little of the hard realities of life and the law;" she expressed the wish that "the lawyers would treat women jurors as human beings."221

Notions regarding women's general lack of fitness as jurors also permeated many cases challenging the exclusion of women from juries. Judicial opinions candidly admitted doubt about whether women had the strength and will to perform jury duty. In the words of one judge, only men qualified as "householders" under the jury eligibility act of the Territory of Washington, because women

were unfitted by physical constitution and mental characteristics to assume and perform the civil and political duties and obligations of citizenship.... The husband was not only the head of the family at common law, because under the law he had the right to be obeyed by all the family, including the wife, but because of the inherent and acquired differences between himself and wife in mental and physical constitution. ... Legislative enactment would not make black white, nor can it provide the female form with bone and sinew equal in strength to that which nature provided man. No more can it reverse the law of cause and effect, and clothe a timid, shrinking woman whose life theater is and will continue to be and ought to continue to be, primarily the home circle, with the masculine will and self-reliant judgment of a man. ${ }^{222}$

Some judges paternalistically rhapsodized the duty of the court to protect the fairer sex. In Bailey v. State, the court upheld the exclusion of women from a defendant's jury pool by explaining:

Criminal court trials often involve testimony of the foulest kind, and they sometimes require consideration of indecent conduct, the use of filthy and loathsome words, references to intimate sex relationships, and other elements that would prove humiliating, embarrassing and degrading to a lady[;] . . . . while the right of Commissioners to call women unquestionably exists, ... a defendant who complains that due process was denied ... must show something more than the continuing failure of jury commissioners to call women for service division of the Court where the innate refinement peculiar to women would be assailed with verbal expressions, gestures, conversations and demonstrations from which most would recoil. ${ }^{223}$

To counter the claim that the differences between women and men left women unqualified to serve, many women's rights advocates argued that precisely because of their inexperience in the public realm, women often made better jurors than men. They suggested that women would tend to listen more care-

220. Women Jurors, supra note 120, at 138 (citing the opinion of a New York judge).

221. L.T.S., Woman and the Law, 3 TEx. B.J. 237, 238, 264 (1940).

222. Rosencrantz v. Territory of Wash., 5 P. 305,311 (Wash. Terr. 1884) (Turner, J., dissenting).

223. Bailey v. State, 219 S.W.2d 424, 428, 429 (Ark. 1929) (emphasis in original). 
fully and clearly to the evidence than would more experienced male jurors.224 Similarly, they argued, women's wealth of vicarious experience would compensate for their lack of knowledge about business and the marketplace. For, as "wives, daughters and sisters of prominent business and professional men whose own service on juries it is practically impossible to procure," these women would often prove better educated and more intelligent than the men actually available for jury service. ${ }^{225}$ Additionally, because women often lived "lives of leisure" that were unavailable to working men, jury commissioners could likely procure the women's services more easily than men's. Women arguably would "serve in many instances on juries when a man [would] ask to and be excused." 226

Beyond simply rebutting the argument that women's inexperience or lack of education made them unfit candidates for jury service, some women's rights advocates argued that women's higher moral sense and perceptions made them better qualified to serve on juries, ${ }^{227}$ and would lead to a greater number of just verdicts. ${ }^{228}$ As Judge Florence Allen remarked,

in calling women to serve as jurors new sources of intelligence are opened and intelligence is surely needed on a jury. The women on a jury follow the evidence well and are unusually conscientious in the verdict. It is the general verdict ... that they will never "play cards nor throw dice" to decide their vote. The women are not particularly sentimental. Neither are they heartless. They are much like men in their usual reactions to evidence, but they are marked by a notable desire for law enforcement. For my part, I believe that in the future we shall owe much to the woman juror because of her respect for law and her conscientious demand that society be protected and the rules of civilized conduct upheld. 229

Ironically, the proponents of gender-difference arguments offered the very same rationales in favor of women's jury service that many courts used to ex-

224. H.H. Sawyer, Women as Jurors, 15 AM. MERCURY 139, 142 (1928) ("[W]omen are more careful and conscientious in their new found duties than men, and are particularly anxious to learn and make good in their new field. Because of their inexperience they pay closer attention to the lawyers, the witnesses, and the instructions of the court."); see also Miller, supra note 80, at 39 (noting that his own experience with women jurors had shown him that "a high type of women [was] being secured, and that individually they [were] alert, intelligent and fair-minded jurors").

225. Sheridan, supra note 80 , at 794.

226. Anderson, supra note 205 , at 198 ; see also note 207 supra and accompanying text. For a creative justification for women's jury service, see Women as Jurors, supra note 120, stating,

It is an interesting prospect, this of having women on our juries. One speculates as to whether their natural tenderness of heart will cause them to be more lenient to wrongdoers than men would be. Or would they conscientiously stifle impulses of mercy and let stern justice be done? Illuminating comparisons of masculine and feminine obstinacy will also be permitted by the new order of things. The more one contemplates the subject the richer are seen to be the possibilities for study of differences in sex psychology.

227. See, e.g., Anderson, supra note 205 , at 198 (suggesting that women bring dignity to the courtroom and that their presence will raise the standard of juries); Jacobs, supra note 205, at 263 (arguing that female jurors can "more accurately discern the motives and determine the truthfulness of the witness").

228. See, e.g., Women as Jurors, supra note 215 , at $57-58$ (commenting that no reason existed to excuse women from cases involving infidelity, obscenity, and immorality, because women are better judges of the truth in such cases than men).

229. Women Jurors, supra note 207, at 224. 
clude women from juries. Gender-difference arguments-like the representativeness model-imply that the need for women's jury service exists only as long as women's presence adds something to the truth-seeking mission of the process. 230 Thus, the double-edged nature of this claim renders suspect even "positive" decisions resulting from its use.

For example, in Taylor v. Louisiana, the Supreme Court invalidated an allmale process based on gender difference arguments. ${ }^{231}$ In reaching its conclusion that the jury selection system violated the fair cross-section requirement of the Sixth Amendment through its de facto exclusion of women from the jury pool, the Court noted that "[c]ontrolled studies of the performance of women as jurors conducted subsequent to the Court's decision in Ballard have concluded that women bring to juries their own perspectives and values that influence both jury deliberation and result." 232 This reliance on arguments that women and men differ kept women vulnerable to peremptory challenges on the basis of sex.

\section{The Current Gender-Difference Debate}

As the Court now recognizes, sex-based stereotypes about jurors have openly formed the basis for peremptory challenges in a way that would patently violate the Constitution in a race context. ${ }^{233}$ Considerations of women's innate ability to serve continue to guide strategic decisions regarding the exercise of peremptory challenges. ${ }^{234}$ Because both parties play a role in selecting jurors during voir dire, lawyers may still use peremptories to exercise any stereotypical notions (except, of course, those based solely on race, and now sex). By

230. See, e.g., Rudolph, supra note 80 , at 100-01.

231. 419 U.S. 522 (1975). For a discussion of the cross-section requirement as explained by the Taylor Court, see Martha Craig Daughtrey, Cross Sectionalism in Jury-Selection Procedures Afier Taylor v. Louisiana, 43 Tenn. L. Rev. 1, 50-82 (1975); Case Comment, Twelve Good Persons and True: Healy v. Edwards and Taylor v. Louisiana, 9 HARv. C.R.-C.L. L. REv. 561 (1974).

232. 419 U.S. at 532 n.12 (citing Robert P. Murray \& Hugh McGinley, Looking as a Measure of Attraction, 3 J. Applied Soc. Psychol. 267 (1972)); see also Wallace M. Rudolph, Women on JuriesVoluntary or Compulsory?, 44 J. AM. Jud. Soc. 206 (1961); Eloise C. Snyder, Sex Role Differential and Juror Decisions, 55 J. Soc. \& Soc. Res. 442 (1971); Fred L. Strodtbeck \& Richard D. Mann, Sex Role Differentiation in Jury Deliberations, 19 SOCIOMETRY 3 (1956).

233. See J.E.B. v. T.B., 114 S. Ct. 1419 (1994). Indeed, United States v. Omoruyi, 7 F.3d 880 (9th Cir. 1993), shows that a belief in gender difference is still being used by prosecutors to attempt to exclude women from jury service. In this case, the prosecutor used a peremptory challenge to strike two women because "he was concerned that these single women would be attracted to the defendant." Id. at 881.

234. See, e.g., Melvin M. Belli, SR., Modern Trials $\S 51.68$ (2d ed. 1982) (cautioning lawyers that "[i]f a plaintiff is a woman and has those qualities which other women envy-good looks, a handsome husband, wealth, social position-then women jurors would be unwise ... [because] [t]hey are the severest judges of their own sex"); MARTIN BLINDER, PsychiatRy IN THE Everyday Practice OF LAW § 12.3(c) (3d ed. 1992) (stating that "[a]ll other things being equal, men are disposed favorably, and woman unfavorably, to the words of an attractive woman"); 1 ANN FAGAN GINGER, JURY SELECTION IN Civil and CRIMnal TRIaLs \$ 4.36 (1984) (suggesting that "[a] woman juror may hold a woman lawyer to a higher standard than she would hold a man," and that women lawyers who adopt aggressive tactics may find themselves alienating the women on a jury); WARD WAGNER, JR., ART OF ADVOCACY-JURY SELECTION § 1.04[9] (1993) (warning lawyers against "strident, self-assertive, or hostile" women who may feel antagonism toward male plaintiffs or male lawyers and suggesting that "[i]f a female juror demands to be addressed as Ms. and not Miss, you probably should take heed"). 
regulating sex-based peremptory challenges, the Court has ensured that the extent of women's and men's rights will no longer depend on the parties' preconceived notions about gender differences.

This regulation was essential to protect women's jury rights; the sheer quantity of empirical and theoretical studies analyzing the connection between gender and juror behavior strongly suggests that gender difference still defines the debate about the desirability and necessity of women as jurors. Despite the arguably inconclusive nature of empirical studies examining the relationship between gender and decisionmaking, ${ }^{235}$ many practitioners seem to rely heavily on their results. ${ }^{236}$ Empirical research regarding the effect of gender difference on juries has focused on two distinct aspects of the jury process: the deliberation and the verdict. Some research hypothesizes that women generally remain relatively silent during jury deliberations and that this silence minimizes the impact of their presence. ${ }^{237}$ Other studies assume that a juror's sex predictively correlates with the verdict the juror will render. ${ }^{238}$

Studies that focus on the effect of sex on jury deliberations assume that the deliberations involve a group process. ${ }^{239}$ Gender difference allegedly enters into the calculus at several crucial points: deciding where to sit in the jury room, ${ }^{240}$ selecting the foreperson, ${ }^{241}$ participating in the discussions, ${ }^{242}$ persuading jurors reluctant to join a struggling minority, ${ }^{243}$ and establishing the

235. Saul M. Kassin \& Lawrence S. Wrightsman, The American Jury on Trial: PsychoLOGICAL PERSPECTIVEs 28 (1988) (stating that atiempts to identify predictable verdict differences have met with limited success).

236. For a sampling of articles explaining why lawyers rely on group predictions, see William $T$. Pizzi, Batson v. Kentucky: Curing the Disease But Killing the Patient, 1987 Sur. CT. Rev. 97, 123-33.

237. See, e.g., Reid Hastie, Steven D. Penrod \& Nancy Pennington, Inside the Jury 141 (1983) (citing research finding that males participated in deliberations more actively than women); Strodtbeck \& Mann, supra note 232, at 5 (finding that male jurors initiate more discussion than female jurors in mock jury trials). But see RIta James Simon, The JuRY and the Defense of INSANITY 11516 (1967) (finding no difference between the participation rates of male and female jurors in criminal cases, but significantly less participation by women than men in civil cases).

238. See, e.g., Kalven \& ZeISEL, supra note 29; Cookie Stephan, Sex Prejudice in Jury Simulation, 88 J. Psychol. 305, 309 (1974) (finding that jurors less often convict a defendant of their own sex); see also VAN DYKE, supra note 29, at 41 (finding that women jurors tend to favor women litigants).

239. See Nancy S. Marder, Gender Dynamics and Jury Deliberations, 96 YALE L.J. 593, 594 (1987); cf. Robert D. Foss, Group Decision Processes in the Simulated Trial Jury, 39 SociomerRY 305, $305 \mathrm{n} .1$ (1976) (arguing that it is "not clear whether we can even meaningfully speak of simulated jurors without employing a group deliberation").

240. See, e.g., Robert Sommer, Leadership and Group Geography, 24 SOcIOMETRY 99 (1961) (reporting on study of how people in small groups seat themselves according to leadership status).

241. See, e.g., HASTIE ET AL., supra note 237, at 28 (finding that jurors who are male, from higher social classes, or sitting at the ends of tables are most frequently elected foreperson); Simon, supra note 237, at 114 (business owners were four times more likely to be selected as foreperson than male laborers, and housewives were never selected); B. Beckham \& H. Aronson, Selection of Jury Foremen as a Measure of the Social Status of Women, 43 PsYCHOL. REP. 475, 475 (1978) (finding that women are elected foreperson one-fifth as often as their numbers would indicate).

242. See, e.g., HASTIE ET AL., supra note 237, at 28.

243. See, e.g., id. at 145-46 (finding that male jurors are generally viewed as more persuasive than female jurors); Rita M. James, Status and Competence of Jurors, 64 AM. J. Soc. 563, 567 (1959) (finding that jurors with the highest rate of discussion participation rate were considered the most persuasive). But see SmoN, supra note 237, at 119 (finding that men who participated more frequently did not wield greater influence). 
underlying power relations in and beyond the jury room. ${ }^{244}$ Empirical studies concerning the correlation of sex and verdicts generally focus on one of three factors: the issues or crime involved, ${ }^{245}$ the sex of the parties, ${ }^{246}$ or the physical attractiveness of the defendant. ${ }^{247}$ Most of the empirical work consists of simulated juror studies, and the studies of actual jury verdicts are inconclusive. ${ }^{248}$

Unfortunately, these studies-in which practitioners and courts have put so much stock-do not advance the rights of women under the citizenship model of juries. Instead, they focus solely on the representativeness model, and they offer tentative support at best for including women on juries. If the deliberation studies correctly suggest that women have little impact on a jury's decisionmaking, then seating more women on juries - either by removing systemic barriers or by preventing sex-based peremptory challenges-will not necessarily increase the representativeness of juries or lead to just verdicts. ${ }^{249}$ On the other hand, the sex/verdict correlation studies simply encourage lawyers to use ste-

244. See, e.g., Rosabeth Moss Kanter, Women and the Structure of Organizations: Explorations in Theory and Behavior, in Another Voice: Feminist Perspectives on Social Life and Social SciENCE 34, 56 (Marcia Millman \& Rosabeth Moss Kanter eds., 1975) (arguing that men and women may not begin a decisionmaking process as peers because of differences in status and power); B.F. Meeker \& P.A. Weitzel-O'Neill, Sex Roles and Interpersonal Behavior in Task-Oriented Groups, 42 AM. Soc. REv. 91, 95 (1977) (arguing that males have higher status and higher performance expectations than females, and thus are able to make more contributions, wield more influence, and receive more approval than females, from whom less is expected); see also Catharine A. MacKinnon, Feminism, Marxism, Method, and the State: Toward Feminist Jurisprudence, 8 Signs: J. WOMEn Culture \& Soc'y 635 (1983) (discussing power relations involving dominance/submission relationships and gender difference).

245. See, e.g., Stephan, supra note 238, at 309 (asserting that women are more lenient and less likely to convict in all criminal cases).

246. See, e.g., Morris J. Bloomstein, Verdict: The Jury System 65 (1968) ("Where women are parties in the case, most lawyers are loathe to retain women jurors, since they are thought to be harder on their own sex."); Samuel W. McCart, Trial by JuRY: A Complete Guide to the JuRY System 33 (2d ed. 1964) ("There is a general impression among lawyers that male jurors, out of gallantry, favor women litigants and so, when representing a woman, they seek an all-male jury which will overlook female deceit another woman would spot at once.").

247. See, e.g., Michael G. Efran, The Effect of Physical Appearance on the Judgment of Guilt, Interpersonal Attraction, and Severity of Recommended Punishment in a Simulated Jury Task, $8 \mathrm{~J}$. ReS. Personalrty 45 (1974); Harold Sigall \& Nancy Ostrove, Beautiful But Dangerous: Effects of Offender Attractiveness and Nature of the Crime on Juridic Judgment, 31 J. PersonalrTy \& Soc. PsYCHoL. 410, 412-13 (1975) (finding that both men and women are more likely to give lenient treatment to attractive defendants than to unattractive defendants).

248. See Cookie Stephan, Selective Characteristics of Jurors and Litigants: Their Influences on Juries' Verdicts, in THE JURY SYSTEM IN AMERICA 97, 113 (Rita James Simon ed., 1975). The author found that "[t]he experimental data in which the sex of the juror served as an independent variable established few consistent differences between the decisions of male and female jurors." However, "[t]he bulk of the data suggested that men are more active in jury deliberations than women and thus may be more influential in determining verdicts." This author and many other researchers have concluded that much of the data on the effect of female jurors on deliberations and verdicts is anecdotal rather than experimental, and in any case, contradictory. Id. at 115.

249. See Marder, supra note 239, at 612 (concluding that "[w]omen have a lower participation rate than men during deliberations" and that "active verbal participation is essential for finding the facts, applying the law to the facts, and rendering an accurate verdict that represents the values of the community"); see also Laura Gaston Dooley, Sounds of Silence on the Civil Jury, 26 VAL. U. L. REv. 405 (1991) (arguing that there is very little correlation between the mythology of women jurors and empirical evidence about the impact of gender on verdicts largely due to inequality in the deliberation process). 
reotypes to predict the behavior of prospective jurors. Notwithstanding the conclusions of the deliberation and sex/verdict correlation studies, and regardless of whether their voices are heard or their minds are read, seating women on juries will increase their participation in public life and further the appearance and the experience of women as full citizens.

Nonempirical arguments that women jurors differ from men jurors also arise. They tend to fall into two categories: unarticulated hunches that women are different, and theories about the different perspective or "voice" of women in interpreting facts and law. Unsupported assumptions and stereotypical notions about gender difference frequently appear in modern cases invalidating jury selection schemes that systematically exclude women. These assumptions parallel the speculations in early legal commentary that the presence of women would make some-though largely inarticulable-difference. ${ }^{250}$ They also tend to follow assumptions made in support of the inclusion of blacks on juries.

For example, in explaining the harm caused by race-based exclusions of prospective jurors, a plurality in Peters $v$. Kiff held:

When any large and identifiable segment of the community is excluded from jury service, the effect is to remove from the jury room qualities of human nature and varieties of human experience, the range of which is unknown and perhaps unknowable. It is not necessary to assume that the excluded group will consistently vote as a class in order to conclude, as we do, that its exclusion deprives the jury of a perspective on human events that may have unsuspected importance in any case that may be presented. ${ }^{251}$

Similarly, the Court rejected the claim in Ballard $v$. United States that an allmale jury could represent the community as well as one that included women:

It is said, however, that an all male panel drawn from the various groups within a community will be as truly representative as if women were included. The thought is that the factors which tend to influence the action of women are the same as those which influence the action of men-personality, background, economic status-and not sex. Yet it is not enough to say that women when sitting as jurors neither act nor tend to act as a class. Men likewise do not act as a class. ... The truth is that the two sexes are not fungible; a community made up exclusively of one is different from a community composed of both; the subtle interplay of influence one on the other is among the imponderables. To insulate the courtroom from either may not in a given case make an iota of difference. Yet a flavor, a distinct quality is lost if either sex is excluded. The exclusion of one may indeed make the jury less representative of the community than would be true if an economic or racial group were excluded. ${ }^{252}$

In both Peters and Ballard, the Supreme Court derived the right to serve on juries from the representativeness model and struck down an exclusionary scheme based on difference. Because the Court failed to address the citizenship model in both cases, inclusion necessarily required a showing of differ-

250. See text accompanying notes 224-229 supra.

251. 407 U.S. $493,503-04$ (1971).

252. 329 U.S. 187, 193-94 (1946). 
ence. However, now that the jury right for women is a right of citizenship, difference becomes an irrelevant factor in the equation.

Several theorists, led by Carol Gilligan, have tried to define somewhat more rigorously the "flavor" and "distinct quality" noted by the Ballard Court. Gilligan, a psychologist, describes gender difference in terms of moral perceptions: men adhere to an ethic of rights while women follow an ethic of caring. ${ }^{253}$ However, adherents to "different voice" theory also ignore the importance of the citizenship model of the jury's function. A corollary to Gilligan's theory, formulated by Karen Czapanskiy, assumes a gendered system of fact interpretation: Male decisionmakers understand women's experiences differently, if at all, and might perceive credibility and truth differently. ${ }^{254}$ Gretchen Schoff believes that women bring a unique illumination of their own life experiences to a jury, just as every reader brings a special quality to a text. ${ }^{255}$ Wendy Williams argues that

women's life experiences still differ sufficiently from men's that a diverse group of women would bring a somewhat different set of perceptions and insights to certain issues than would a similarly diverse group of men.

This observation about the importance of representation among decisionmakers is no less relevant to the judiciary or to juries than to legislatures. ${ }^{256}$

The empirical research and theories described above have been incorporated into the fight for jury rights as support for arguments that juries should include women precisely because they are different. But since courts analyzing sexually discriminatory jury selection have focused on gender difference to the exclusion of citizenship rights, these theories and studies failed as bars to sexbased peremptory challenges. Paradoxically, allowing sex-based challenges nullifies "at the voir dire stage what the women's movement worked so hard from 1919 to 1975 to achieve-the opportunity for women to be tried before a jury that includes female members."257 Although special-sphere justifications for and against women's jury service have become obsolete, the gender difference arguments relying on the unique (good or bad) perspective and qualifications of women persist today. Thus, without the protection of J.E.B. the combination of persistent stereotypes and the freedom accompanying peremptory challenges would continue to effectively deprive women (and men) of

253. Carol Gilligan, In a Different Voice: Psychological Theory and Women's DevelopMENT 64-105 (1982).

254. Karen Czapanskiy, Gender Bias in the Courts: Social Change Strategies, 4 Geo. J. Legal Etrics 1, 4 (1991) (arguing that judges "may be unable to accord the same credibility to a woman's testimony as they would to a man's," but that in an ideal world, a decisionmaker would "understand women's experiences so well that he or she can interpret the law in situations involving women without instinctively favoring men's needs or crediting men's experience").

255. Gretchen H. Schoff, Women, Justice, and Judgment, 4 LAw \& INEQ. J. 137 (1986) (comparing the reactions of male and female judges to various literary texts and observing that the women focused on the theme of need, the characters' capacity for careful listening, "the difficulties for women of handling power and authority without sacrificing compassion, and the moral quandaries surrounding crimes of domestic violence").

256. Williams, supra note 190 , at 175 n.2.

257. Mahoney, supra note 40 , at 215 . 
their citizenship-based right to serve on juries by simply relocating the historical exclusion of women to a new context.

\section{CONCLUSION}

The history of women's exclusion from juries is crucial to understanding the import of J.E.B. v. T.B. For many years, women were completely excluded from juries. When they eventually served, it was not because courts granted women the right to serve, but rather because of their perceived differencestheir unique contribution. Barriers to service were removed only because women were seen to add something to the jury process; their rights were limited by the needs of defendants and courts. At the same time, jury rights for blacks were treated as worthy of independent constitutional protection. This disparity persisted despite the long struggle of women's rights advocates, mirroring the battle by blacks, to include women on juries as a function of their citizenship.

Sex-based peremptory challenges are simply another vestige of the subordination of women. Women argued for jury rights in terms of citizenship beginning in the late nineteenth century. Courts ignored these arguments, focusing instead on challenges based on representativeness. In limiting the possible arguments in the context of sex, but not of race, courts ensured that the inconsistent application of jury selection principles persisted until 1994. In J.E.B. $v$. $T . B$., the Supreme Court boldly eliminated this inconsistency by shifting its analytical framework to accommodate a simple fact: Racially and sexually discriminatory peremptory challenges both infringe upon basic citizenship rights. Concluding that exclusion on the basis of sex "denigrates the dignity of the excluded juror, and, for a woman, reinvokes a history of exclusion from political participation," the Court has finally recognized the importance of both the citizenship and the representativeness models of jury selection in cases of sexbased, as well as race-based exclusion from juries. ${ }^{258}$ For juries to fulfill their dual function of scrutinizing facts and providing a forum for the exercise of citizenship rights, jury selection principles must consider the rights of prospective jurors as well as defendants in all cases. The shift-accomplished by the Supreme court's simple acknowledgement that the exclusion of jurors on the basis of sex inflicts comparable harm to exclusion on the basis of race-is of great significance in the progression toward women's equal rights under the Constitution. 